\title{
Research \\ Shorter Fallow Cycles Affect the Availability of Noncrop Plant Resources in a Shifting Cultivation System
}

\author{
$\underline{\text { Sarah Paule Dalle }}^{1}$ and Sylvie de Blois ${ }^{2}$
}

\begin{abstract}
Shifting cultivation systems, one of the most widely distributed forms of agriculture in the tropics, provide not only crops of cultural significance, but also medicinal, edible, ritual, fuel, and forage resources, which contribute to the livelihoods, health, and cultural identity of local people. In many regions across the globe, shifting cultivation systems are undergoing important changes, one of the most pervasive being a shortening of the fallow cycle. Although there has been much attention drawn to declines in crop yields in conjunction with reductions in fallow times, little if any research has focused on the dynamics of noncrop plant resources. In this paper, we use a data set of 26 fields of the same age, i.e., $\sim 1.5 \mathrm{yr}$, but differing in the length and frequency of past fallow cycles, to examine the impact of shorter fallow periods on the availability of noncrop plant resources. The resources examined are collected in shifting cultivation fields by the Yucatec Maya in Quintana Roo, Mexico. These included firewood, which is cut from remnant trees and stumps spared at the time of felling, and 17 forage species that form part of the weed vegetation. Firewood showed an overall decrease in basal area with shorter fallow cycles, which was mostly related to the smaller diameter of the spared stumps and trees in short-fallow milpas. In contrast, forage species showed a mixed response. Species increasing in abundance in short-fallow milpas tended to be short-lived herbs and shrubs often with weedy habits, whereas those declining in abundance were predominantly pioneer trees and animal-dispersed species. Coppicing tree species showed a neutral response to fallow intensity. Within the cultural and ecological context of our study area, we expect that declines in firewood availability will be most significant for livelihoods because of the high reliance on firewood for local fuel needs and the fact that the main alternative source of firewood, forest patches, has also declined in shortfallow areas. Declines in some forage species can likely be compensated for by the use of other species or by adaptive responses such as managing declining species in home gardens. However, the loss of pioneer tree species in short-fallow milpas suggests that the regenerative capacity of the fallows may be reduced with implications for maintaining effective fallow cycles in this shifting cultivation system. Our findings indicate that the dynamics of noncrop plant resources and their implications for local livelihoods require further consideration in the debate over improving the productivity of shifting cultivation systems.
\end{abstract}

Key Words: agricultural intensification; ethnobotany; fuelwood; land-use change; Mexico; milpa; Quintana Roo; resource scarcity; slash-and-burn; swidden agriculture; tropical succession; wild plant resources; Yucatec Maya.

\section{INTRODUCTION}

Shifting cultivation systems, one of the most ancient and widely distributed forms of agriculture in the tropics, create a very dynamic landscape mosaic of fields, fallows, and forests at different stages of succession. Such systems provide not only crops of cultural significance such as corn in the milpas of Mexico (Esteva and Marielle 2003), but also medicinal, edible, ritual, fuel, and forage resources that are harvested from a diversity of wild plant species (Alcorn 1981, Bye 1981, Levy Thatcher and Hernández Xolocotzi 1992, Colfer et al. 1997, Schmidt-Vogt 1997, Frei et al. 2000, Toledo et al. 2003). Tolerated or actively managed in cultivated or regenerating patches (e.g., see Alcorn 1981), these species can make significant contributions to the livelihoods, health, and cultural identity of local 
people (Johns 1994, Mazhar and Buckles 2000, Vieyra-Odilon and Vibrans 2001).

In many regions across the globe, shifting cultivation systems are undergoing important changes, one of the most pervasive being a reduction of the fallow period. This is occurring as a consequence of a variety of factors such as increased population pressure, changes in land tenure and/or land access, and declines in labor availability (Ramakrishnan 1992, Kellman and Tackaberry 1997, Brookfield 2001, Finegan and Nasi 2004). In other instances, government policies and conservation organizations have encouraged farmers to shorten fallow periods (Dalle et al. 2006) based on the perception that this will reduce deforestation (but see Sunderlin 1997).

Although there has been much attention drawn to declines in crop yields in conjunction with shorter fallow periods (Mertz 2002), little if any research has focused on the dynamics of plant resources other than staple crops. However, ecological studies suggest that important changes at both the patch and landscape scale could impact noncrop plant resources in short-fallow systems. First, short fallow periods often result in a more homogenous landscape mosaic dominated by young secondary vegetation (Metzger 2003, Dalle 2006), thereby reducing the availability of resources from older forest patches (e.g. see Pulido and Caballero 2006). Second, plant diversity, density, and composition in shifting cultivation fields and secondary forests have been reported to differ between short and long fallow management (Illsley Granich 1984, Saxena and Ramakrishnan 1984, Staver 1991, de Rouw 1995, Fujisaka et al. 2000), and with repeated cycles of shifting cultivation (Lawrence 2004, Lawrence et al. 2005). Therefore, such ecological changes could affect the availability and distribution of noncrop plant resources and the rural livelihoods that depend on them.

In this study, we combine ecological and ethnobotanical data to analyze the dynamics of noncrop plant resources in the shifting cultivation system practiced by the Yucatec Maya in Quintana Roo, Mexico. Using a data set of 26 fields of the same age, i.e., $\sim 1.5 \mathrm{yr}$, but differing in the length and frequency of past fallow cycles, we examine the impact of shorter fallow cycles on the availability of forage and firewood, two noncrop plant resources that are collected from shifting cultivation fields. Whereas forage is collected from a variety of species including trees, shrubs, herbs, and vines that form part of the weed vegetation (Fig. 1), firewood is derived from the remnant trees and stumps that are spared at the time of felling (Fig. 2). Given the relative lack of both ethnobotanical and ecological analyses of the dynamics of noncrop plant resources in relation to changing fallow histories, we aim to (1) assess the extent to which the availability of such resources are impacted by changes in fallow periods, (2) discuss some of the ecological processes and management practices that drive changes in their abundance, and (3) consider the potential implications of our findings for local livelihoods and for the productivity of shifting cultivation systems.

\section{STUDY AREA}

Research was conducted in the Ejido X-Maben, in the Municipio Felipe Carrillo Puerto located in the central part of the state of Quintana Roo, Mexico. The population is nearly entirely Yucatec Maya, and in 2000 was estimated at 2849 people, $83 \%$ of whom live in the largest village, Señor (INEGI 2000).

The vegetation in X-Maben is generally described as medium semideciduous tropical forest (selva mediana subperrenifolia) in the Mexican classification system, with a maximum stature of approximately $15 \mathrm{~m}$, shedding approximately $25 \%$ of its foliage in the dry season (Flores and Espejel Carvajal 1994, Pennington and Sarukhán 1998). The environment is karstic, being characterized by thin limestone-derived soils, mostly lithosols and rendzinas, and an underground drainage system with many caverns and sinkholes (Flores and Espejel Carvajal 1994). Average annual temperatures are approximately $26^{\circ} \mathrm{C}$, whereas average annual precipitation ranges from $1200-1500 \mathrm{~mm} / \mathrm{yr}$ (Instituto de Geografía 1990), with a marked dry season occurring from January to April.

Shifting cultivation, referred to locally as "milpa" in Spanish, or kool in Maya, is practiced by nearly all households in X-Maben (Murphy 1990, Dalle 2006). The main crops are maize, beans, and squash, the seeds of which are planted together. Other crops such as various types of tubers, watermelon, other squashes, and gourds can be interplanted among these main crops. Vegetation is typically cleared during the dry season using an axe and/or machete, although for older vegetation clearing may begin earlier. Fields are burned in April or May and 
Fig. 1. Don Reynaldo browsing his horse in a $\sim 1.5$-yr-old milpa. The vegetation is typical of our shortfallow sites.

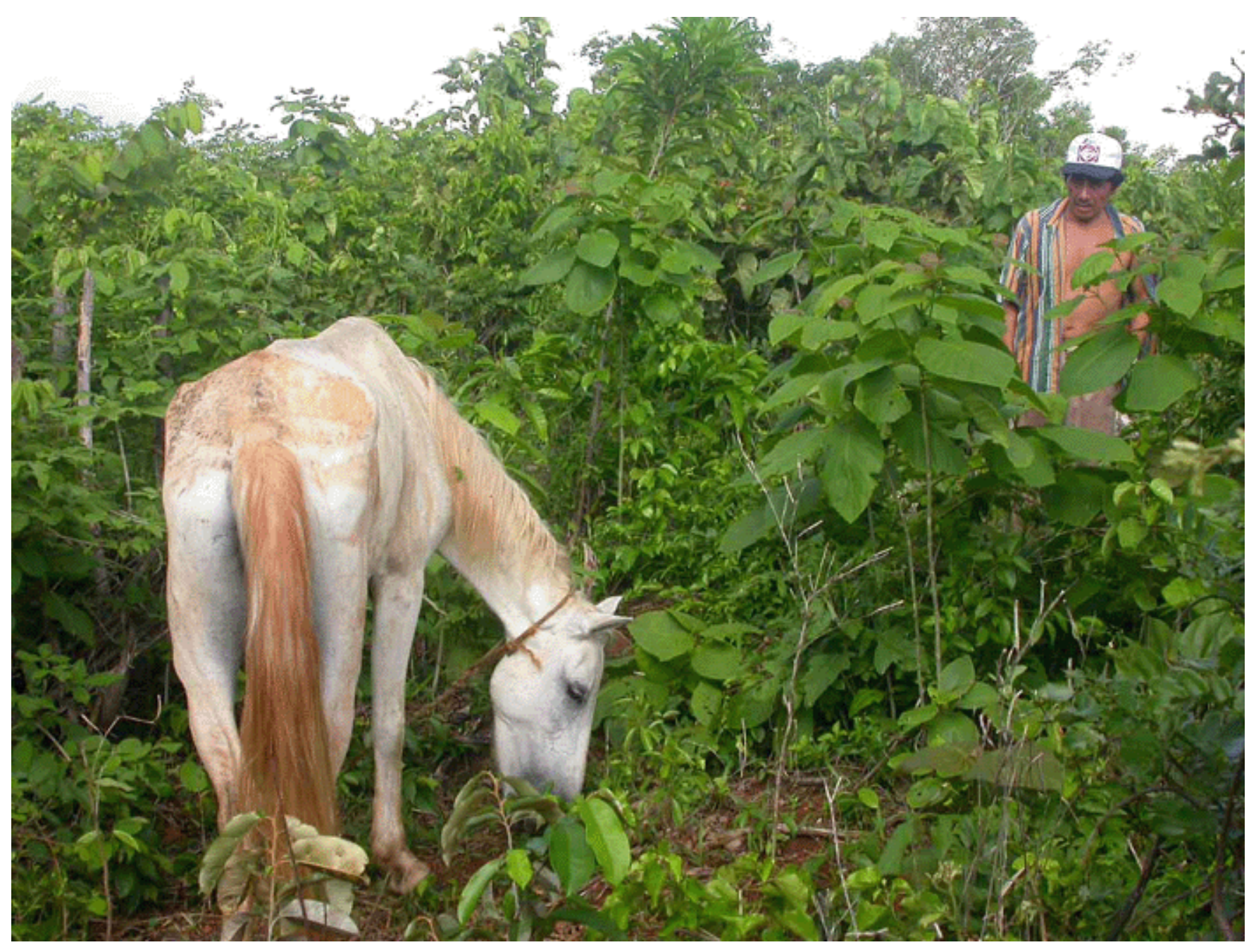

planted following the first rains, generally in May or June. Use of inorganic fertilizers, manually applied at the base of each corn plant, is widespread. Weeding is performed by hand, usually not more than once in the growing season; use of chemical herbicides is rare. Although farmers often stated that $\sim 8-10$ yr of fallow are necessary to avoid high weed loads, fallow periods practiced in X-Maben vary widely. In 2003, households in Señor felled vegetation between 5 and approximately 40-60 yr of age for their main milpa, with $40 \%$ choosing sites less than 10-yr old. These short-fallow milpas are more common in the more accessible areas surrounding the village (Dalle 2006).
Nearly all households in X-Maben depend on firewood as their main source of fuel (Dalle 2006). A few of the most well-off families have gas stoves, but even these use firewood for part of their cooking needs. Many people also place burning coals below their hammocks to keep warm at night in the cooler months of December and January. Firewood is collected principally by men, but women and children also participate. In the milpa firewood is collected from trees and stumps that are spared at the time of felling (Fig. 2). Although the rootstocks of these generally resprout after the burn, the aboveground parts are usually killed, thereby providing an excellent source of standing dry wood. 
Fig. 2. Spared stumps (A) and trees (B) in a recently burned milpa. Don Brigido is preparing a load of firewood cut mostly from spared trees, seen at the bottom right of photograph. Two substrate types (Fig. 3) are also apparent: $k^{\prime} a n k a b$ in the foreground and wool wool tunich in the background.

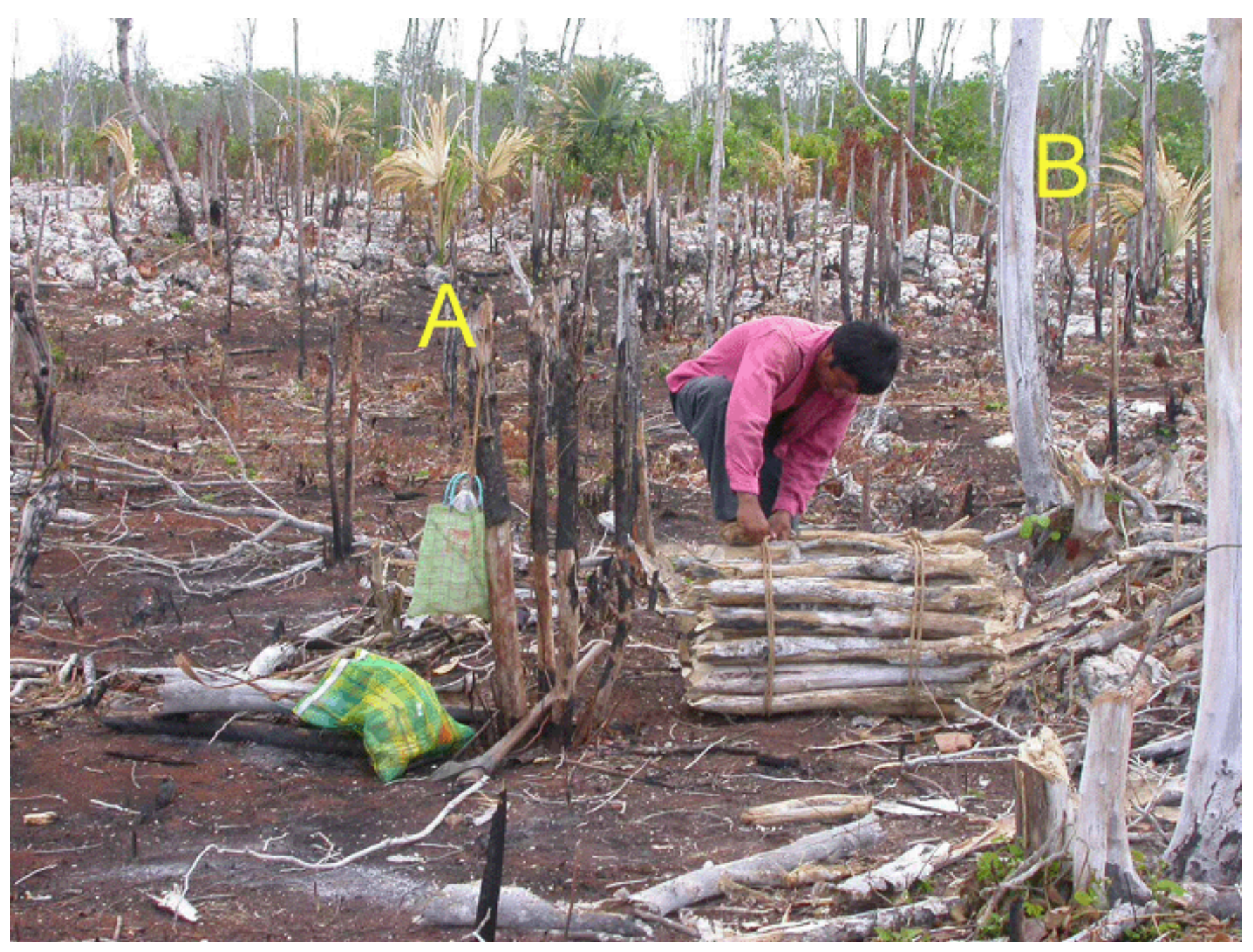

Older forest patches are the second main source of firewood (Dalle 2006), especially those found in a few forest reserves nearby the villages (see Dalle et al. 2006). Younger secondary and burned forests are also used to a lesser degree (Dalle 2006).

Animal husbandry is an important activity among the Maya, with the sacrifice of pigs playing a central role in a number of Maya rituals and ceremonies (Pohl and Feldman 1982). In 2003, in the largest village Señor, $78 \%$ of households raised local breeds of pigs, $15 \%$ "Americano" or modern breeds, whereas $71 \%$ and $29 \%$ raised chickens and turkeys, respectively (Dalle, unpublished data). Women are generally responsible for care of these animals, which are kept in the home garden. Although horses were once important for transportation, today less than $10 \%$ do so, whereas cattle and sheep are produced by some for cash income. These larger animals, often being kept at ranches away from the home, are generally cared for by men. Forage is the basis of the diet for horses, sheep, and cattle. Small animals are fed a combination of corn and forage, although in some households only corn is used. The 
Table 1. Forage species included in this study, with their uses and importance ranking according to focus groups with men and women. Animals are $\mathrm{P}=$ pigs, $\mathrm{Ch}=$ chickens, $\mathrm{T}=$ turkeys, $\mathrm{H}=$ horses, $\mathrm{Sh}=\mathrm{sheep}$, $\mathrm{C}=$ cattle.

\begin{tabular}{|c|c|c|c|c|c|c|c|c|c|c|c|c|}
\hline \multirow[t]{2}{*}{ Maya name } & \multirow[t]{2}{*}{ Scientific name } & \multirow[t]{2}{*}{ Family } & \multirow[t]{2}{*}{ Code $^{1}$} & \multirow[t]{2}{*}{ Voucher $^{2}$} & \multicolumn{2}{|c|}{ Ranking $^{3}$} & \multicolumn{6}{|c|}{ Animals fed } \\
\hline & & & & & Men & Women & $\mathrm{P}$ & $\mathrm{Ch}$ & $\mathrm{T}$ & $\mathrm{H}$ & Sh & $\mathrm{C}$ \\
\hline Púut ch'íich' & Carica papaya $\mathrm{L}$. & Caricaceae & CARI & 362 & 1 & 1 & 1 & 1 & 1 & 1 & 1 & \\
\hline Ya'ax kanal & $\begin{array}{l}\text { Psychotria nervosa } \\
\text { Swartz }\end{array}$ & Rubiaceae & PSYC & $\begin{array}{l}263,279 \\
296\end{array}$ & 1 & 2 & 1 & & & 1 & 1 & 1 \\
\hline K'an chim & Panicum sp. & Poaceae & PANI & 272 & 1 & 2 & & 1 & & 1 & 1 & 1 \\
\hline Ya'axnik & Vitex gaumeri Greenm. & Verbenaceae & VITE & 266 & 1 & 2 & & & & 1 & 1 & 1 \\
\hline Ch'ilitu'ux & $\begin{array}{l}\text { Acalypha unibracteata } \\
\text { Muell. Arg. }\end{array}$ & Euphorbiaceae & ACAL & 330 & 1 & 3 & 1 & & & 1 & 1 & 1 \\
\hline X-K'o'och & Cecropia peltata $\mathrm{L}$. & Cecropiaceae & CECR & 267,276 & 1 & 3 & & & & 1 & 1 & 1 \\
\hline $\begin{array}{l}\text { Yo'och oop' } \\
\text { tsíimin }\end{array}$ & Petrea volubilis L. & Verbenaceae & PETR & 252 & 1 & 3 & & & & 1 & 1 & 1 \\
\hline Jobom k'áak' & $\begin{array}{l}\text { Euphorbia heterophylla } \\
\text { L. }\end{array}$ & Euphorbiaceae & EUPH & 264 & 1 & . & & & & 1 & 1 & 1 \\
\hline Paak' um paak' & $\begin{array}{l}\text { Desmodium incanum D. } \\
\text { C. }\end{array}$ & Fabaceae & DESM & 282 & 1 & . & & & & 1 & 1 & 1 \\
\hline Tah & $\begin{array}{l}\text { Viguiera dentata (Cav.) } \\
\text { Spreng. var. } \\
\text { heliantoides (HBK.) } \\
\text { Blake }\end{array}$ & Asteraceae & VIGU & 333 & 1 & . & & & & 1 & 1 & 1 \\
\hline Toplanxix & $\begin{array}{l}\text { Melanthera aspera } \\
\text { (Jacq.) Small }\end{array}$ & Asteraceae & MELA & 265 & 1 & . & & & & 1 & 1 & 1 \\
\hline K'aniste' & $\begin{array}{l}\text { Pouteria campechiana } \\
\text { (HBK.) Baehni }\end{array}$ & Sapotaceae & POUT & 269 & 1 & . & & & & 1 & 1 & 1 \\
\hline Xeret' & $\begin{array}{l}\text { Centrosema schotti } \mathrm{K} . \\
\text { Schum. }\end{array}$ & Fabaceae & CENT & 310 & 1 & . & & & & 1 & 1 & 1 \\
\hline Chak kanal & Hamelia patens Jacq. & Rubiaceae & HAME & 245,297 & 1 & . & & & & & 1 & 1 \\
\hline $\begin{array}{l}\text { Toon toon } \\
\text { tsíimin }\end{array}$ & Passiflora pedata $\mathrm{L}$. & Passifloraceae & PASS & 309 & 1 & . & & & & 1 & & \\
\hline Telkox & $\begin{array}{l}\text { Phytolacca icosandra } \\
\text { L. }\end{array}$ & Phytolaccaceae & PHYT & 311 & 3 & 3 & & & 1 & & & \\
\hline Paux & $\begin{array}{l}\text { Trema micrantha }(\mathrm{L} .) \\
\text { Blume }\end{array}$ & Ulmaceae & TREM & 242 & 3 & . & & & & 1 & 1 & 1 \\
\hline
\end{tabular}

${ }^{1}$ This code, the first four letters of the genus name, is used to indicate species in the figures ${ }^{2} \mathrm{~S}$. Dalle collection numbers

${ }^{3}$ Rankings represent the perceived importance of each species relative to other forage plants; Rank 1 is the most important, Rank 3 the least. 
Table 2. Species ranked as good or high quality firewood resources included in this study.

\begin{tabular}{|c|c|c|c|c|}
\hline Maya name & Species name & Family & Code $^{1}$ & Voucher $^{2}$ \\
\hline Pe'eresk'uuch & Croton arboreus Millsp. & Euphorbiaceae & & 251,256 \\
\hline Kokche' & Croton icche Lundell & Euphorbiaceae & & 307 \\
\hline P'ii & Gymnanthus lucida Swartz & Euphorbiaceae & & 363 \\
\hline Tsu'urontok & Bauhinia divaricata $\mathrm{L}$. & Fabaceae & & $\begin{array}{l}\text { MEC 50, 55, 69, } \\
135\end{array}$ \\
\hline Kitamche' & Caesalpinia gaumeri Greenm. & Fabaceae & CAES & 352 \\
\hline Sak ya'ap & Gliricidea sepium (Jacq.) Steud. & Fabaceae & & 347 \\
\hline Taasta'ab & Guettarda combsii Urban & Fabaceae & & 292 \\
\hline K'anasin & Lonchocarpus rugosus Benth. & Fabaceae & & MEC 105 \\
\hline Tsalam & Lysiloma latisiliquum (L.) Benth. & Fabaceae & LYSI & 270 \\
\hline Ja'abin & Piscidia piscipula (L.) Sarg. & Fabaceae & PISC & MEC 255 \\
\hline K'atal óox & Swartzia cubensis (Britton \& P. Wilson) Standley & Fabaceae & & 350 \\
\hline X-Jochok & Nectandra coriacea (Lundell) Kostermans & Lauraceae & NECT & 290 \\
\hline K'an jóol & Abutilon gaumeri Standley & Malvaceae & & MEC 68 \\
\hline Chak ni' che' & Ardisia revoluta $\mathrm{HBK}$ & Myrsinaceae & & MEC 54 \\
\hline Sakloobche' & Eugenia sp. & Myrtaceae & & MEC 83 \\
\hline Pichi' che' & Psidium sartorianum (Bergius) Niedenzu & Myrtaceae & & 293 \\
\hline Ch'íich' boob & Coccoloba cozumelensis Hemsl. & Polygonaceae & & MEC 280, 355 \\
\hline Boob & Coccoloba spicata Lundell & Polygonaceae & $\mathrm{COCC}$ & MEC 129 \\
\hline Ts'its'il che' & Gymnopodium floribundum Rolfe & Polygonaceae & & MEC 201 \\
\hline Ja'as che' & Alseis yucatanensis Standley & Rubiaceae & & MEC 322,353 \\
\hline Sabakche' & Unidentified & Rubiaceae & & 284 \\
\hline K'anchunup & Thouinia paucidentata Radlk. & Sapindaceae & & 288 \\
\hline Chi' kéej & Crysophyllum mexicanum T.S. Brandegee ex. Standley & Sapotaceae & & MEC 59 \\
\hline Ts'its'il ya' & Dipholis salicifolia (L.) A.DC. & Sapotaceae & & MEC 140, 271 \\
\hline K'askáat & Luehea speciosa Willd. & Tiliaceae & & MEC $86,117,168$ \\
\hline
\end{tabular}


"Americano" breed of pig is usually raised on commercial feed. Forage plants are obtained from a variety of habitats including the milpa, the home garden, and ruderal environments. These are usually collected and brought to the animals, although larger animals, such as horses, cattle, and sheep, can also be taken to the milpa to browse.

\section{METHODS}

Fieldwork for this study was conducted between November 2002 and October 2003, during which time the first author resided in the main village Señor. All stages of the project, including species and site selection and the vegetation sampling, were conducted in close collaboration with several local assistants. These included a man with a secondary school education and two men who had extensive knowledge of the local vegetation.

\section{Study species}

Seventeen forage species were selected for study, based on their importance as a resource and also to represent a range in life-forms and reproductive strategies (Table 1). Each species' use and its relative importance as a resource were identified in a set of focus groups held with men and women in Señor (see Dalle 2006 for more details). Of the 17 species, nearly all are used as forage for horses, sheep and cattle, whereas 5 are used for pigs or fowl. The preferred species for this latter purpose is wild Carica papaya L.

To examine the amount of firewood left standing as trees and stumps in fields, a list of firewood species and their quality was developed using interviews and focus groups (see Dalle 2006). A total of 25 firewood species considered as high or good quality were identified (Table 2). Of these, the regeneration of five of the preferred firewood species (Caesalpinia gaumeri Greenm., Coccoloba spicata Lundell, Lysiloma latisiliquum (L.) Benth., Nectandra coriacea (Lundell) Kostermans, and Piscidia piscipula (L.) Sarg.) were examined along with the forage species. This was done to better evaluate the response of resprouting tree species to fallow history, since these were not well represented among the forage species.

\section{Site selection}

A total of 26 sites were selected to represent a gradient of short to long fallow times. All sites were milpas that had been cultivated in the 2002 agricultural cycle, e.g., burned in April-May 2002, for the first time after a fallow period of at least 5 yr. Most milpas had not been cropped again in the 2003 cycle; in cases in which a portion of the milpa had been cropped a second time, only the uncropped areas were sampled. A second criterion guiding site selection was that the history of each site, in terms of the number of milpa cycles, and the age of vegetation felled, needed to be relatively well known. The sampled areas of the milpas ranged from $0.5-5$ ha, with an average size of 1.7 ha.

The sites included milpas that had been felled from two forest types recognized by the local Maya population. These differ in their degree of deciduousness, presumably responding to variations in edaphic conditions in the study area. The first is called k'an lu'um k'áax (KL) and is more deciduous, whereas the second, yáax k'áax (YK) is more evergreen. In both cases they are identified by local Maya farmers by their species composition. In early successional state, $\mathrm{KL}$ is identified by the prevalence of trees such as Acacia pennatula (Schldt. and Cham.) Benth., Pithecellobium albicans (Kunth.) Benth., and Lysiloma latisiliquum (L.) Benth, whereas Nectandra coriacea (Lundell) Kostermans is considered indicative of the more evergreen YK. Similar forest types are distinguished by Maya in other parts of the Yucatan Peninsula (Illsley Granich and Hernández Xolocotzi 1980). Because of the potential relationship between these forest types and other variables in our study, we stratified our sampling by selecting 10 milpas in the deciduous KL and 16 in the more evergreen YK. In both cases these represented a gradient of short to long fallow histories, however, YK tends to be more intensively used, and we have more short-fallow milpas of this forest type in our data set.

\section{Fallow cycle histories}

Site histories were identified through interviews with the owners of each milpa. For some sites, this involved talking with several people since more than one farmer had been known to work the site. Our interviews were generally conducted with the member of the household who had the prime 
responsibility for selecting and felling the site, although in some cases other family members were consulted. All informants were men.

In each case, farmers were asked to estimate the age of vegetation felled and the number and length of previous cycles. In most cases we were able to obtain histories dating back to 1960 . We attempted to verify the estimated dates of the successive cycles by referring to key events that most people in the area remember. These included events such as hurricanes, floods, the paving of access roads, and several government programs for agricultural credit. Thus, when asking farmers to recall information on previous cycles, we asked whether they had worked the site before or after a given event. In other cases, we verified dates of specific events mentioned in the interview, such as a marriage or land-use conflict, by consulting relevant certificates or other independent sources. Referral to such events helped to confirm estimated lengths of cycles. Furthermore, when several farmers were interviewed regarding a given site, histories could be verified by examining consistency in the information reported.

For the 26 sites, the length of the last fallow cycle ranged from an estimated $5 \mathrm{yr}$ to approximately 40 $\mathrm{yr}$, and there were 1-5 cycles since 1960 . In a few cases, disturbances or land uses not related to milpas were reported to have occurred. These included a government-sponsored cattle pasture, which operated between 1966 and 1979, and some wild fires. In the case of the cattle pasture, we sampled several milpas representative of a full gradient of short to long fallow times, and thus assumed that any influence of this history on our data would be spread out among fallow periods. Wild fires were reported to have occurred in four sites. We considered these to constitute a "cycle" equivalent to milpa, assuming that many of the trees died and a process of secondary succession was initiated.

\section{Vegetation sampling}

Sampling occurred from August to October 2003. All milpas were approximately 1.5 -yr old with respect to the date of the last burn. A systematic sampling design was used in which each milpa was sampled using a grid of $2 \mathrm{~m}$ radius circular plots, spaced evenly at $15 \mathrm{~m}$ intervals across the entire milpa. This produced approximately 36 sampling plots/ha. For our 26 sites, the mean number of sampling plots was 56, with a range of 21 to 151 . Site-level estimates of relative frequency of the forage species and densities of spared trees were later calculated based on the total number of occurrences or abundances divided by the number of sampling plots per site.

The vegetation sampling was carried out by a team of four people, consisting of the first author (SPD), a local assistant who recorded the field data, and two vegetation experts who identified plant species according to their Maya names and helped measure other variables.

In each circular plot, we recorded the presence/ absence of the 17 forage and 5 firewood focal species, and the Maya name of all spared trees and of spared stumps $>70 \mathrm{~cm}$ in height. Trees or stumps that had already been cut for firewood were also recorded. The basal diameter of these harvested stumps or trees, as well as that of standing stumps was measured, whereas the diameter at breast height was recorded for spared trees. Despite having been burned, both spared trees and stumps could be identified by the vegetation experts based on the characteristics of their wood and bark, and of the leaves of resprouting root suckers and coppice shoots. The percent of each plot occupied by plant cover, including the focal species, was estimated visually using a 7 -point scale $(<10 \%, 10-25 \%, 25-$ $40 \%, 40-60 \%, 60-75 \%, 75-90 \%,>90 \%)$.

In addition to vegetation data, we also collected information on other ecological variables that could be related to fallow history and the observed vegetation patterns. Our field observations indicated that substrate could be important for understanding the distribution of the species, so we characterized the substrate in each 2 m circular plot. By "substrate" we refer to the conformation of the soils and limestone rock outcrops that characterize the karstic environment (Weisbach et al. 2002). These outcrops are extremely variable and differentially weathered such that they can form soil-filled depressions of different extents and depth, be flat outcrops covered by only a slight layer of soil, or be broken up into boulders or smaller rocks, with soil accumulating in the crevices. These different conditions influence regeneration niches and cultivation potential (Illsley Granich and Hernández Xolocotzi 1980, Illsley Granich 1984), and contribute to explaining differences in forest communities (Sanchez Sanchez and Islebe 2002, White and Hood 2004). In order to characterize 
these edaphic conditions, we used the local Maya terminology to identify five types of substrate (see Fig. 3). Use of Maya edaphic terms is a common practice in the Yucatan Peninsula, often being more detailed and practical than available scientific classifications (Barrera-Bassols and Toledo 2005). For each 2-m circular plot we estimated the percentage represented by each of these categories. Site-level estimates of the relative cover of each substrate type were calculated by summing the percentage of sampled area associated to each type and dividing by the number of plots.

Finally, since landscape context, or the surrounding vegetation, can influence plant colonization patterns (Purata 1986, Martinez-Garza and Gonzalez-Montagut 1999), at each site we drew a sketch map indicating the type of vegetation bordering the milpa, and estimated the proportion of the milpa perimeter with mature forests $>25 \mathrm{yr}$. In addition, we estimated the amount of mature forest in the surrounding landscape by extracting the number of pixels classified as mature forest (> 25 yr) within a $500 \mathrm{~m}$ radius from a classified LANDSAT image from February 2000 (see Dalle et al. 2006 for more details). Voucher specimens for all firewood and forage species were collected either by SPD or obtained through a concurrent study (Correo Cano 2004). The vouchers were identified and deposited at MEXU in Mexico City.

\section{Data analysis}

\section{Measures of fallow history and rockiness}

As described above, we obtained information on two measures of fallow history: (1) the length of the last fallow period expressed in years, and (2) the number of cycles since 1960 . Herein, we refer to these variables as "fallow length" and "number of cycles," respectively. "Fallow history" refers to both variables together.

Fallow length and the number of cycles were negatively correlated (Spearman $r_{\mathrm{s}}=-0.862, P$ $<0.001)$. Thus, milpas with shorter fallow periods tended to have been subjected to a greater number of fallow cycles. Since either one or the other of these two variables has often been used in the literature to describe fallow history, here we present separate results for each variable to facilitate comparison with other studies. However, in the present paper, fallow history should be conceived of as a gradient from long, infrequent fallow cycles to short, frequent cycles.

The data on substrate types for all plots in a site were summarized by using a quantitative variable representing the degree of rockiness. To do so, we performed a PCA on the relative cover of each of the five substrate types. The first PCA axis, defined as the variable "rockiness," represented a gradient from sites with a low proportion to those with a high proportion of rocky substrate types (Fig. 3). The PCA was performed using CANOCO for Windows, v. 4.5.

\section{Relationships between fallow history, site characteristics, and standing firewood}

For spared firewood stumps and trees, the total basal area for each site was calculated including only the 25 good quality firewood species shown in Table 2 . In cases in which the tree or stump had already been cut, presumably for firewood, it was assumed that it had been a spared tree if the basal diameter was $>6 \mathrm{~cm}$, the average minimum diameter of spared trees (Table 3); otherwise it was considered to have been a stump. Note that for analyses on firewood, data from one short-fallow site could not be used, thus the sample size was 25 .

To assess the impact of shorter fallow periods on firewood availability, we calculated correlations of fallow history with firewood density, minimum stump/tree diameter, mean stump/tree diameter, and basal area. Correlations of fallow history with other site characteristics such as surrounding vegetation, density, and rockiness were also performed. The Spearman rank correlation coefficient, $r \mathrm{~s}$, was used since some variables were highly skewed and could not be normalized. Correlations were calculated using SYSTAT for Windows, v. 9.

Relative influence of fallow history, rockiness, and forest type on the frequency of forage and firewood species

We examined the relative influence of four explanatory variables, i.e., fallow length, number of cycles, rockiness, and forest type on the frequency of the 17 forage and five firewood species. This was done using redundancy analysis (RDA), a form of 
canonical analysis that produces an ordination of a multivariate data set, the species frequencies in this case, constrained by a linear combination of explanatory variables (Legendre and Legendre 1998).

Two sets of analyses were carried out. First, we examined an RDA of the species frequencies vs. the four explanatory variables. A forward selection procedure was used to ensure that all variables added a statistically significant independent effect. Second, we controlled for the effect of forest type, assigning this as a covariable, and examined the relative importance of fallow history and rockiness in explaining the species frequencies using partial canonical analysis (Legendre and Legendre 1998). This method allows a partitioning of the variation in the species data into three fractions: [a] that explained by fallow history alone, $[\mathrm{b}]$ that explained jointly by fallow history and rockiness, and [c] that explained by rockiness alone. This allowed us to test whether a significant independent effect could be attributed to fallow history.

We used RDA rather than canonical correspondence analysis, since RDA has the advantage of not assigning differential weights to sites according to the number of species present (Legendre and Gallagher 2001). However, RDA is generally not appropriate for analyzing species data especially when unimodal species-environment relationships are present. Therefore, transformed the species data to make them amenable to analysis by RDA, according to the method proposed by Legendre and Gallagher (2001). Of the five transformations proposed by Legendre and Gallagher (2001), the "distance between species profiles" was selected since it produced the RDA with the strongest species-environment relationship. RDAs were conducted with the program CANOCO for Windows v. 4.5. All tests of significance in CANOCO were carried out with 999 permutations under the reduced model.

\section{RESULTS}

\section{Relationship among fallow history, site characteristics, and standing firewood}

Fallow history was correlated with a number of other site characteristics (Table 4). In particular, longer fallow cycles were associated with more surrounding mature forest, less dense vegetation cover in the milpa and rockier soils. Longer fallow cycles also showed a significant positive correlation with the maximum and mean dbh of spared trees, but not with their density or minimum dbh. Correlations with the number of cycles showed similar patterns (Table 4).

Overall, 41 folk species were recorded as spared trees, and 100 as spared stumps. Of the 25 species considered as preferred firewood in this study, 20 occurred as spared trees and all were encountered as stumps. These preferred firewood species represented nearly $50 \%$ of all species encountered as spared trees, but only $25 \%$ of those found as spared stumps. The species most frequently spared as trees or stumps were Piscidia piscicula, Coccoloba spicata, Lysiloma latisiliquum, and Lonchocarpus rugosus, with P. piscicula being the most common spared tree at $80 \%$ of the sites, and C. spicata the most frequent spared stump at $100 \%$ of the sites. Whereas 13 firewood species were encountered in more than $50 \%$ of sites as stumps, only 3 were found as spared trees at this frequency. Thus, spared firewood stumps were generally represented by more species than were spared trees.

The amount of preferred firewood species left as spared trees and stumps varied substantially among sites. Overall, the total basal area of spared stumps ranged from 0.7 to $9.9 \mathrm{~m}^{2} / \mathrm{ha}$, whereas spared trees ranged from $0.15-7.8 \mathrm{~m}^{2} /$ ha (Table 3 ). With shorter, more frequent fallow cycles, the maximum and mean diameters as well as the basal areas of both spared stumps and trees of preferred firewood decreased significantly (Table 3, Fig. 4). However, there was no significant relationship between fallow history and the density of either stumps or trees (Table 3, Figs. 4b, e). Thus, decreases in the basal area with shorter fallow periods were due to the smaller size of trees and stumps in sites felled from younger vegetation, rather than differences in density. Visual inspection of scatterplots of firewood basal area vs. fallow length indicated similar trends between the KL and YK forest types (data not shown).

\section{Relative influence of fallow history, rockiness, and forest type, on the frequency of forage and firewood species}

Overall, the 17 forage and 5 firewood species were widely distributed, with most being present in more than $80 \%$ of the sites. The exceptions were Cecropia 
Fig. 3. Schematic representation of Maya substrate types used to describe variation in edaphic conditions in this study. Grey fill indicates zones of soil accumulation. Local names are $\mathrm{A}=$ kon kon lu'um, $\mathrm{B}=$ laja or tsek'el, $\mathrm{C}=$ wool wool tunich, $\mathrm{D}=$ ch'iich lu'um, $\mathrm{E}=k$ 'ankab. Types $\mathrm{A}-\mathrm{C}$ tend to have high organic content, whereas types $\mathrm{D}$ and $\mathrm{E}$ tend to be redder in color, corresponding roughly to lithosols and rendzinas, respectively (Weisbach et al. 2002). The inset shows the relative position of each substrate type along the PCA axis, which we defined as our rockiness index, ranging from sites with a high proportion of plots with less rocky types $\mathrm{D}$ and $\mathrm{E}$, to those with a high proportion of plots with rockier types $\mathrm{A}$ and $\mathrm{B}$.

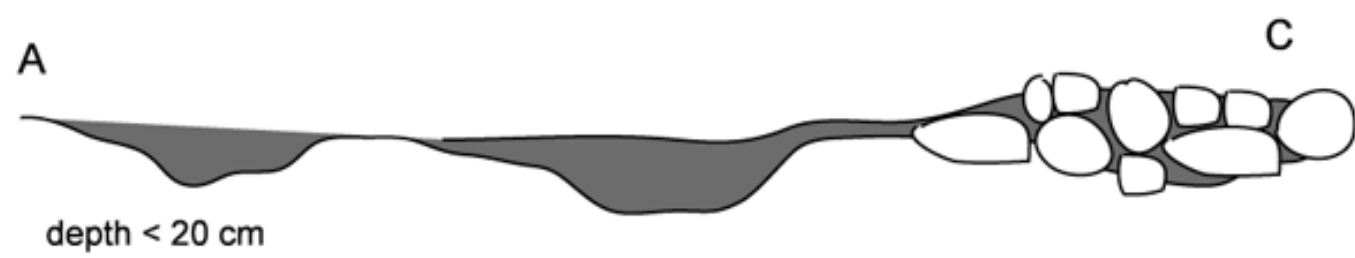

B

depth $<10 \mathrm{~cm}$

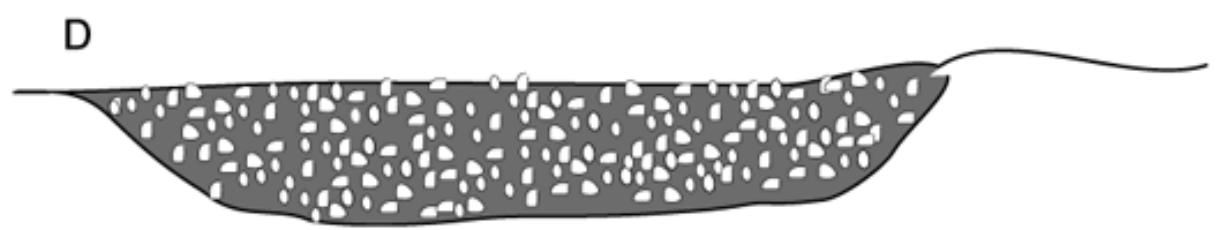

depth $50 \mathrm{~cm}$ - several meters

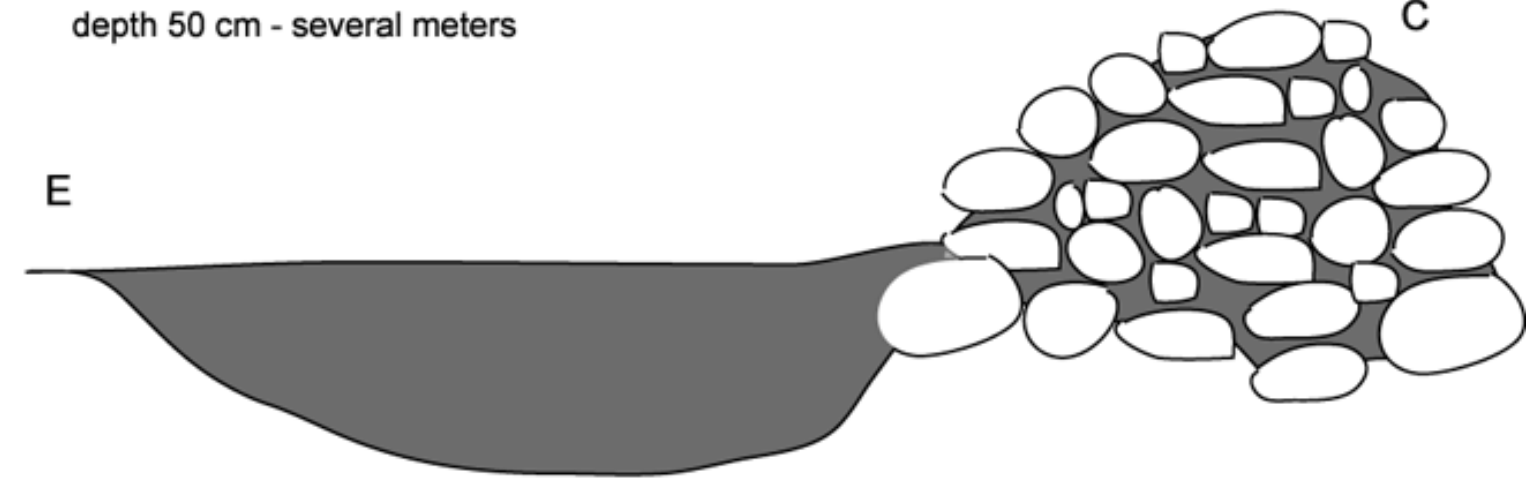

depth $50 \mathrm{~cm}$ - several meters

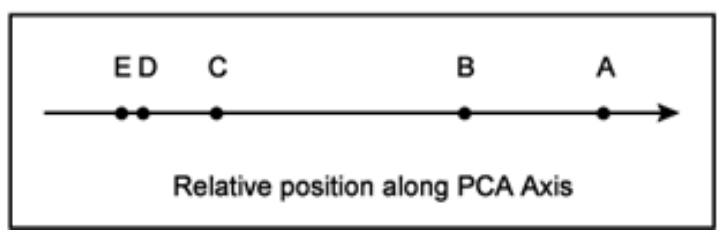


Table 3. Descriptive statistics for diameter, density, and basal area of spared trees and stumps of the preferred firewood species, and Spearman rank correlations of these variables with fallow history, the length of the last fallow period, and the number of cycles.

\begin{tabular}{|c|c|c|c|c|}
\hline \multirow{2}{*}{$\begin{array}{l}\text { Variable } \\
S T U M P S\end{array}$} & \multirow[t]{2}{*}{ Mean $^{1}$} & \multirow[t]{2}{*}{ Range } & \multicolumn{2}{|c|}{ Spearman rank $r_{\mathrm{s}}$} \\
\hline & & & Fallow length & Number of cycles \\
\hline Minimum diameter $(\mathrm{cm})$ & 3.1 & $3-4$ & $-0.383 \mathrm{~ns}$ & $0.118 \mathrm{~ns}$ \\
\hline Maximum diameter $(\mathrm{cm})$ & 15.4 & $6.1-33$ & $0.792 * * *$ & $-0.744 * * *$ \\
\hline Mean diameter $(\mathrm{cm})$ & 6.6 & 4.4-11.7 & $0.741 * * *$ & $-0.694 * * *$ \\
\hline Density (stems/ha) & 1212 & $300-2307$ & $-0.082 \mathrm{~ns}$ & $0.076 \mathrm{~ns}$ \\
\hline Basal area $\left(\mathrm{m}^{2} / \mathrm{ha}\right)$ & 4.4 & $0.7-9.9$ & $0.736^{* * *}$ & $-0.681 * * *$ \\
\hline \multicolumn{5}{|l|}{ TREES } \\
\hline Minimum diameter $(\mathrm{cm})$ & 6.0 & $2.2-11$ & $0.041 \mathrm{~ns}$ & $-0.021 \mathrm{~ns}$ \\
\hline Maximum diameter $(\mathrm{cm})$ & 19.7 & $4.5-42$ & $0.799 * * *$ & $-0.792 * * *$ \\
\hline Mean diameter $(\mathrm{cm})$ & 11.1 & $3.1-19.8$ & $0.781 * * *$ & $-0.714 * * *$ \\
\hline Density (stems/ha) & 237 & $43.5-954$ & $-0.110 \mathrm{~ns}$ & $-0.012 \mathrm{~ns}$ \\
\hline Basal area $\left(\mathrm{m}^{2} / \mathrm{ha}\right)$ & 2.4 & $0.15-7.8$ & $0.552 * *$ & $-0.578 * *$ \\
\hline
\end{tabular}

${ }^{1}$ Mean of estimates for each site $(n=25)$

$* P<0.05, * * P<0.01, * * * P<0.001, \mathrm{~ns}=$ not significant

peltata, Viguiera dentata, Phytolacca icosandra, Centrosema schotti, and Melanthera aspera, which were present in $69 \%$ to $50 \%$ of the sites. Among sites, species varied greatly in their relative frequencies, with the maximum relative frequency ranging between $11 \%$ for Phytolacca icosandra and 96\% for Panicum sp. (Fig. 5). Although most species had minimum relative frequencies near zero, three (Trema micrantha, Coccoloba spicata, and Piscidia piscicula) occurred in at least $10 \%-20 \%$ of sampling plots at any given site.

In the redundancy analysis (RDA) of the relative frequency of the 22 species vs. fallow length, number of cycles, rockiness, and forest type, the forward selection procedure retained all four variables indicating that they all contributed a significant $(P<0.05)$ independent effect. The resulting ordination was significant $(F=6.738, P=$ 0.001 ) and explained $56.2 \%$ of the variation in the species data. Separately, forest type explained $30 \%$ of the variation in the species data, fallow length explained $28 \%$, number of cycles explained $25 \%$, and rockiness explained $9 \%$ of the variation.

Figure 6 shows the correlation biplot resulting from this analysis. Examination of the biplot reveals the three species most strongly related to long fallow cycles: Carica papaya, Trema micrantha, and Phytolacca icosandra. Those more strongly associated to sites with short, frequent fallow cycles were the shrubs Viguiera dentata, Melanthera aspera, Desmodium incanum and, to a lesser extent, Centrosema schotti. The shorter length of this latter species' vector indicates that less of its variation was explained. Sites with short fallow cycles tended 
to be less rocky and had more evergreen YK sites, whereas sites with histories of longer fallow cycles were rockier and more associated to the deciduous KL vegetation. Thus, some of the species negatively associated with short fallow cycles, especially Passiflora pedata, Cecropia peltata, and Lysiloma latisiliquum were more frequent in the more deciduous KL sites, whereas others were more frequent in rockier sites, e.g., Vitex gaumeri and Acalypha indica. Similar relationships are evident among the species more associated with short fallow cycles.

In the partial canonical analysis we found that, overall, $34.7 \%$ of the species variation was explained by fallow history and rockiness, after controlling for forest type. Of this explained variation, $64.8 \%$ was attributable to fallow history alone, $18.4 \%$ to a joint effect of fallow history and rockiness, and $16.9 \%$ to rockiness alone. The fraction corresponding to fallow history alone, i.e., fraction a, was statistically significant $(F=4.139$, $P=0.001)$. Figure 7 shows the amount of the variation explained by each of the three fractions for each species; these are presented in order of their response to fallow history. In general, the overall relationship between species frequencies and fallow history is similar to that found in the full RDA (Fig. 6 ), with the same groups of species associated to short and long fallow cycles. By comparing the length of the species vectors in Fig. 6, which is proportional to the amount of variation explained, with the amount of variation explained in the partial canonical analysis (Fig. 7), it is evident that some species had a much smaller proportion of their variation explained after controlling for forest type, e.g., Cecropia peltata, Lysiloma latisiliquum, and Passiflora pedata. In other instances a large proportion of the variation explained was due to a joint effect of fallow history and rockiness or to that of rockiness alone, e.g., Viguiera dentata, Acalypha indica, and Caesalpinia gaumeri. Nonetheless, for many species, between $20 \%$ and $40 \%$ of the variation in their relative frequencies was attributable to an independent effect of fallow history.

\section{DISCUSSION}

The shortening of fallow periods in shifting cultivation has been reported as a widespread phenomenon in many parts of the tropics and is often associated with declining crop yields. Our findings indicate that the availability of some noncrop resources can also be negatively affected. In particular, we found that firewood showed an overall decrease with shorter, more frequent fallow cycles. Forage species showed a mixed response with some being positively, and others negatively, associated with shorter cycles. Here we discuss some of the ecological and management factors that may influence the availability of these resources and consider the implications of these changes for local livelihoods. A conceptual framework summarizing the proposed relationships between fallow history and resource availability (Fig. 8) is presented to guide future research on this topic.

\section{Forage: dynamics of resources in the spontaneous weed vegetation}

In general, the mixed responses of forage species can be attributed to different reproductive strategies that are selected for in short- vs. long-fallow milpas. Short-lived, heliophilic shrubs and herbs were more frequent in short-fallow milpas, whereas longfallow species tended to be trees establishing primarily by seed, including several pioneer trees, as well as species with fleshy fruits dispersed by birds and other animals (Table 5). These ecological patterns can be explained by a number of different conditions existing in short- vs. long-fallow milpas at both the patch and landscape scale (Fig. 8).

The most easily interpretable trend in our data is the increased frequency of heliophytic short-lived herbs and shrubs, such as Viguiera dentata, Melanthera aspera, Desmodium incanum, Euphorbia heterophylla, and Panicum sp., in short-fallow milpas. This finding is consistent with other studies that have reported an increase in the density of herbs and arable weeds with shorter fallow periods (Illsley Granich 1984, Saxena and Ramakrishnan 1984, Staver 1991, de Rouw 1995, Fujisaka et al. 2000). This occurs because the young fallows that are felled in short fallow cycles have high loads of these species in the seed bank (Young et al. 1987, Staver 1991, Rico-Gray and Garcia-Franco 1992, Quintana-Ascencio et al. 1996). Also, burns in short-fallow milpas are less intense and, therefore, less efficient in reducing the seed bank (Saxena and Ramakrishnan 1984). Together, these two factors lead to a heavy weed load in short-fallow milpas, a trend that may be accentuated after repeated cycles. With longer fallow periods, seed rain of these species is reduced by the establishment of the 
Table 4. Spearman rank correlations of length of the last fallow period and the number of cycles with other site characteristics $(n=25)$.

\begin{tabular}{lll}
\hline \hline Variable & & Spearman rank $r_{\mathrm{s}}$ \\
\hline Landscape context & Fallow length & Number of Cycles \\
Percentage of milpa perimeter with mature forest & $0.510^{* *}$ & $-0.622^{* *}$ \\
Amount of mature forest in 500 m radius & $0.391^{*}$ & $-0.581^{* *}$ \\
Spared trees (all spp.) & & \\
Density & $-0.055 \mathrm{~ns}$ & $-0.048 \mathrm{~ns}$ \\
Minimum dbh of spared trees & $-0.024 \mathrm{~ns}$ & $0.042 \mathrm{~ns}$ \\
Maximum dbh of spared trees & $0.804^{* * *}$ & $-0.779^{* * *}$ \\
Mean dbh of spared trees & $0.772^{* * *}$ & $-0.693^{* * *}$ \\
Density of vegetation & & \\
Percentage of plots with vegetation cover $>90 \%$ & $-0.542^{* *}$ & $0.420^{*}$ \\
Substrate & & \\
Rockiness & $0.444^{*}$ & $-0.409^{*}$ \\
\end{tabular}

$* P<0.05, * * P<0.01, * * * P<0.001, \mathrm{~ns}=$ not significant

canopy, and with time, propagules already in the seed bank lose viability (Saxena and Ramakrishnan 1984, de Rouw 1995).

Species with the ability to regenerate from root sprouts might also be favored in successive shortfallow milpa cycles by increasing their density through repeated coppicing (Lawrence 2004, Lawrence et al. 2005). For example, Desmodium incanum resprouts from its woody stem (SPD, personal observation). This, combined with its extremely adhesive seeds that are effectively dispersed by humans and animals, might contribute to its strong association with short fallow cycles. However, with the exception of Caesalpinia gaumeri, the relative frequency of long-lived coppicing trees did not increase with shorter fallows. Instead, species such as Pouteria campechiana, Nectandra coriacea, Piscidia piscicula, and Coccoloba spicata showed a neutral response, whereas Vitex gaumeri declined. This could be due to the fact that we examined relative frequency rather than stem density. Although multiple coppicing events would be expected to increase stem density, colonization of new sites through seed dispersal or lateral root suckers (Nyerges 1989) would be necessary for these species to increase their relative frequency. In any case, the fact that the only long-lived tree with poor coppicing ability, Lysiloma latisiliquum, declined in short-fallow milpas, indicates that coppicing may be an important strategy for surviving in shortfallow milpas.

The high proportion of fleshy fruits among longfallow species, i.e., six of the eight long-fallow species (Table 5), suggests that these species face dispersal limitation in short-fallow milpas. This could be due to the fact that short-fallow milpas have less mature forest in the surrounding landscape as 
Fig. 4. Scatterplots of mean diameter, density, and basal area against length of the last fallow cycle for spared stumps $(\mathrm{a}-\mathrm{c})$ and spared trees $(\mathrm{d}-\mathrm{f})$. Data based on the 25 firewood species only. Spearman rank correlations and significance levels from Table 3 are indicated in the bottom right corner of each scatterplot.

STUMPS
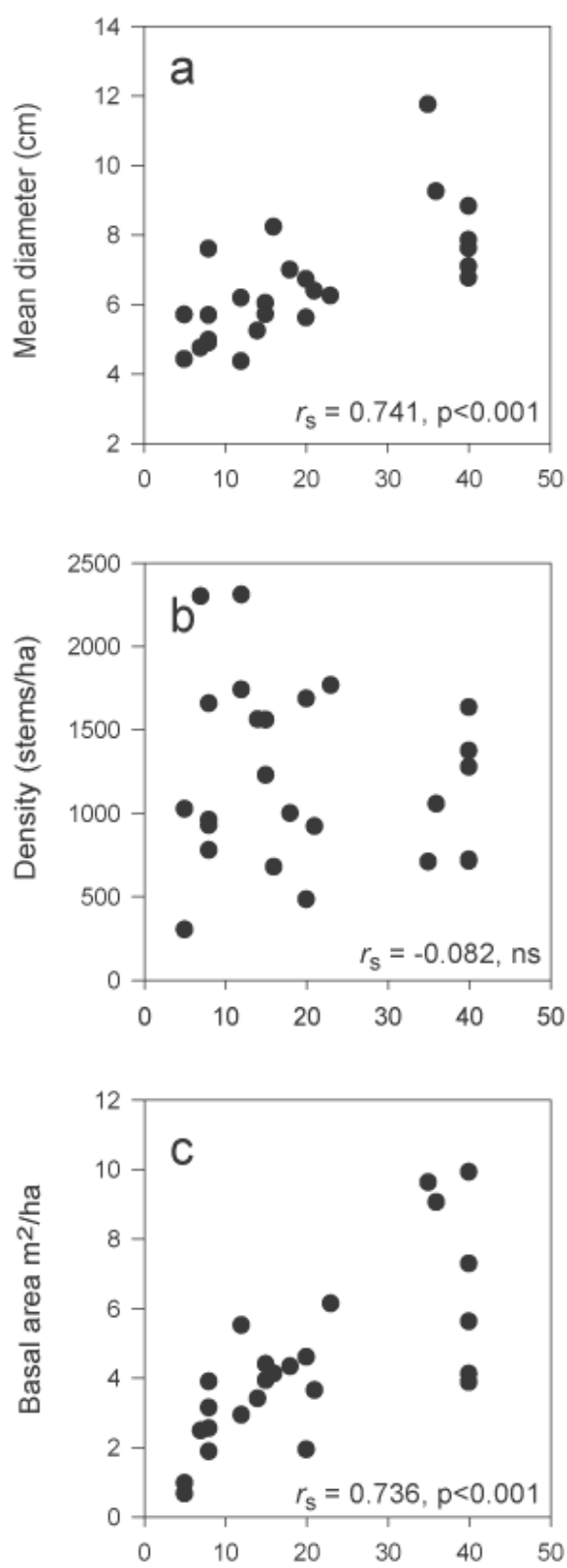

TREES
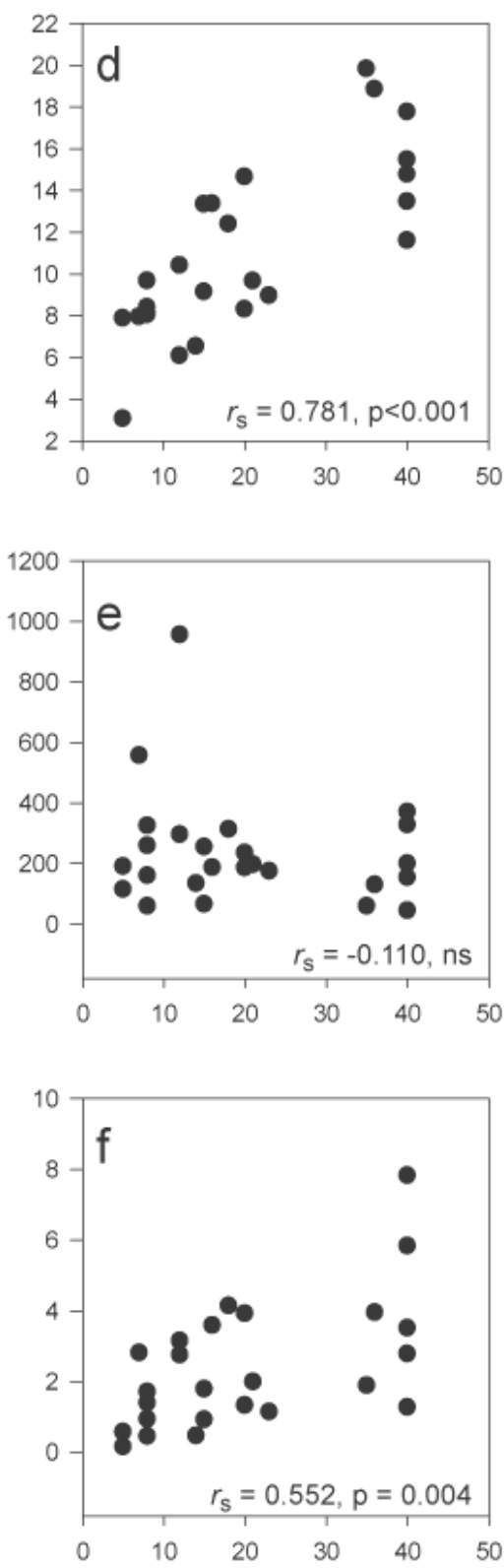

Length of last fallow cycle (yr) 
compared to long-fallow milpas (Table 4). This occurs since short fallow periods are concentrated in accessible areas, and with time, older forest patches are eliminated (Dalle 2006). Similar relationships between fallow practices and landscape structure have been reported in Indonesia (Lawrence 2004) and the Amazon (Metzger 2003), indicating that this is likely a widespread trend. Although species in our study are early successional and hence do not rely on dispersal from mature forest, declines in surrounding forest cover could reduce their colonization of short-fallow milpas if their dispersal vectors use a combination of early and late successional habitats. Lawrence (2004) suggested such a possibility to explain declines in the density of early successional tree species in 9 to 12-yr-old fallows with increased distance from the forest.

A second factor, which could contribute to dispersal limitation in short-fallow milpas are the smaller remnant trees (Table 4). Remnant trees promote the dispersal of woody and especially bird-dispersed species in pastures (Uhl et al. 1982, Guevara et al. 1986) and shifting cultivation fields (Carriere et al. $2002 b$, Carriere et al. 2002a) by providing perches for bird vectors. However, the smaller remnant trees of short-fallow milpas (Table 4) may be less ideal perches for fruit-dispersing birds, due to their smaller branches that quickly break after the burn. This, along with the more homogeneous structure of short-fallow landscapes could explain the decline in fleshy-fruited species such as Carica papaya, Trema micrantha, Cecropia peltata, Passiflora pedata, and Phytolacca icosandra in short-fallow milpas.

Finally, even when long-fallow species are able to disperse into short-fallow milpas, they likely face competitive exclusion by aggressive short-lived species (e.g., as suggested by Purata 1986), which, as discussed above, establish quickly from the seed bank. This is especially significant for a species with low longevity in the seed bank, such as Cecropia spp., which relies on continued seed rain for regeneration in forest gaps (Alvarez-Buylla and Martinez-Ramos 1990, Dalling et al. 1998). Germination of this, and other species with limited viability in the soil bank, could therefore be inhibited due to shading from more quickly established competitors.

\section{Firewood: ecology and management of remnant vegetation}

Firewood is managed in the milpa system by sparing trees and stumps from the original vegetation at the time of felling. Thus, whereas the availability of forage largely depends on ecological processes governing plant establishment and competition in early stages of succession, the response of firewood depends on the condition of the original vegetation and sparing practices.

The significant decrease in the basal area of spared trees and stumps in milpas with shorter, more frequent fallow cycles is related to the smaller diameter of trees in such milpas. Although the younger age of the vegetation felled is the most evident explanation for the smaller tree sizes, it is also possible that the more frequent fallow cycles in short-fallow milpas may have reduced tree growth rates, thereby contributing to smaller tree sizes (Lawrence et al. 2004).

Variation in sparing practices likely influenced the amount of firewood available by modifying the density of spared trees, which although not related to fallow history, was extremely variable. Indeed, the sites with the highest density of both spared trees and stumps, seen as outliers in Figs. 4b,e with spared tree densities of 954 and 555 stems/ha, and stump densities of more than 2000/ha, were a milpa that had been felled specifically with the goal of extracting firewood to sell in the village, and a very accessible milpa located on the outskirts of the village that had been heavily harvested for firewood. In both cases, this led to slightly higher basal areas compared to other sites with similar fallow history. Although such variations in density and basal area may be due to differences in the original variation (e.g. Read and Lawrence), it is likely that farmers in these two sites attempted to increase the amount of firewood by sparing more trees. Nonetheless, such practices did not compensate for the overall decline in firewood basal area. Indeed, the smaller size of trees of younger fallows imposes a strong constraint on the availability of firewood in the milpas.

\section{Implications for local livelihoods and the productivity of shifting cultivation systems}

In regions where noncrop plant resources contribute significantly to household economies, declines in 
their availability due to shorter fallow periods could have negative impacts on local livelihoods. However, this depends on the relative importance of the resource to the household economy as well as households' abilities to respond and adapt to these ecological changes. Common responses to the scarcity of noncrop resources include substitution by alternative sources, changes in collection strategies, introduction of scarce species into home gardens or other forms of management, and adoption of resource-conserving measures (Brouwer et al. 1997, Mahiri 2003, Pulido and Caballero 2006). Clearly, some of these strategies are less sustainable than others in the long term.

Of the resources examined here, the reduction in firewood is perhaps the most critical, since nearly all households in X-Maben depend on firewood to meet their fuel needs (Dalle 2006). In addition to the spared trees and stumps in the milpa, households also obtain firewood from deadwood in nearby forest patches. However, as in other short-fallow shifting cultivation landscapes (Metzger 2003), the cover of nearby forest patches has also declined as fallow times have shortened in the most accessible locations of our study area (Dalle 2006), reducing both principal sources of firewood (Fig. 8). Since the 1970s, the use of bicycles and motor vehicles has enabled better access to more distant forest patches and an internal firewood market, among villagers, has emerged. Nevertheless, access to these alternatives likely varies among households (Brouwer et al. 1997) and some, especially those with limited male labor or cash income, may be more vulnerable to increasing problems of firewood scarcity. Over the long term, finding ways to encourage the regeneration of more forest patches within the agricultural areas (see Dalle et al. 2006) will be necessary to improve the management of this resource.

In X-Maben, the use of forage is less widespread than firewood, with approximately $65 \%$ of households in Señor reporting forage use in 2003 (Dalle, unpublished data). In part, this is due to the small number of households now owning horses, which in the past were a principal form of transportation (Hostettler 1996) and which required large amounts of forage, often of a variety of species, on a daily basis. Although nearly all households keep pigs especially for their use in Maya rituals, use of wild forage is more variable. However, even when forage is important to the household economy, a number of alternatives appear to be available. Our data show that species in the milpa show mixed responses to shorter fallow cycles. As a result, species declining in the short-fallow milpas could potentially be replaced by a variety of other wild species. Moreover, forage is available not only in the milpa but also in home gardens and ruderal environments. Preferred species declining within the short-fallow milpas such as wild Carica papaya could potentially be introduced in the home garden. Indeed, this species is reported to be managed in home gardens in more deforested areas of the Yucatan Peninsula (Acosta Bustillos et al. 1998) possibly representing an adaptive response to its scarcity in the milpa environment (see Caballero 1994 for an example of this strategy with the thatch palm Sabal yapa).

Although the existence of several potential adaptive responses to deal with forage declines means that this resource may be of less concern than firewood, the ecological trends apparent in the forage data, in particular, the decline of pioneer trees such as Carica papaya and Trema micrantha, raise concerns about maintaining effective fallows in the shifting cultivation system. Pioneer trees, due to their rapid growth, high production of leaf litter and monopodial architecture facilitate nutrient cycling in early stages of succession and contribute to the rapid establishment of a canopy that effectively shades out light loving species (Gomez-Pompa and Vazquez-Yanes 1981, Vázquez-Yanes 1998). As a consequence, their loss from the system could reduce the nutrient cycling capacity of the fallow vegetation whereas a slower establishment of a shade layer means that the fallow period will less effectively reduce the weed load (de Rouw 1995).

\section{CONCLUSION}

The shortening of fallow periods in shifting cultivation has been reported as a widespread phenomenon in many parts of the tropics, and in some cases is even promoted by governments and conservation organizations in order to reduce pressure on older forests. Declines in crop yields are often stated as the main concern associated with shorter fallow cycles, but the results from this study have shown that the availability of two noncrop resources, forage and firewood, can also be negatively affected.

Within the cultural and ecological context of central Quintana Roo, firewood, which is obtained from 
Fig. 5. Range in relative frequency of 17 forage and five firewood species. Circles indicate the minimum and maximum relative frequencies observed for each species. Note that sites where species were absent were excluded. Species' codes as in Tables 1 and 2.

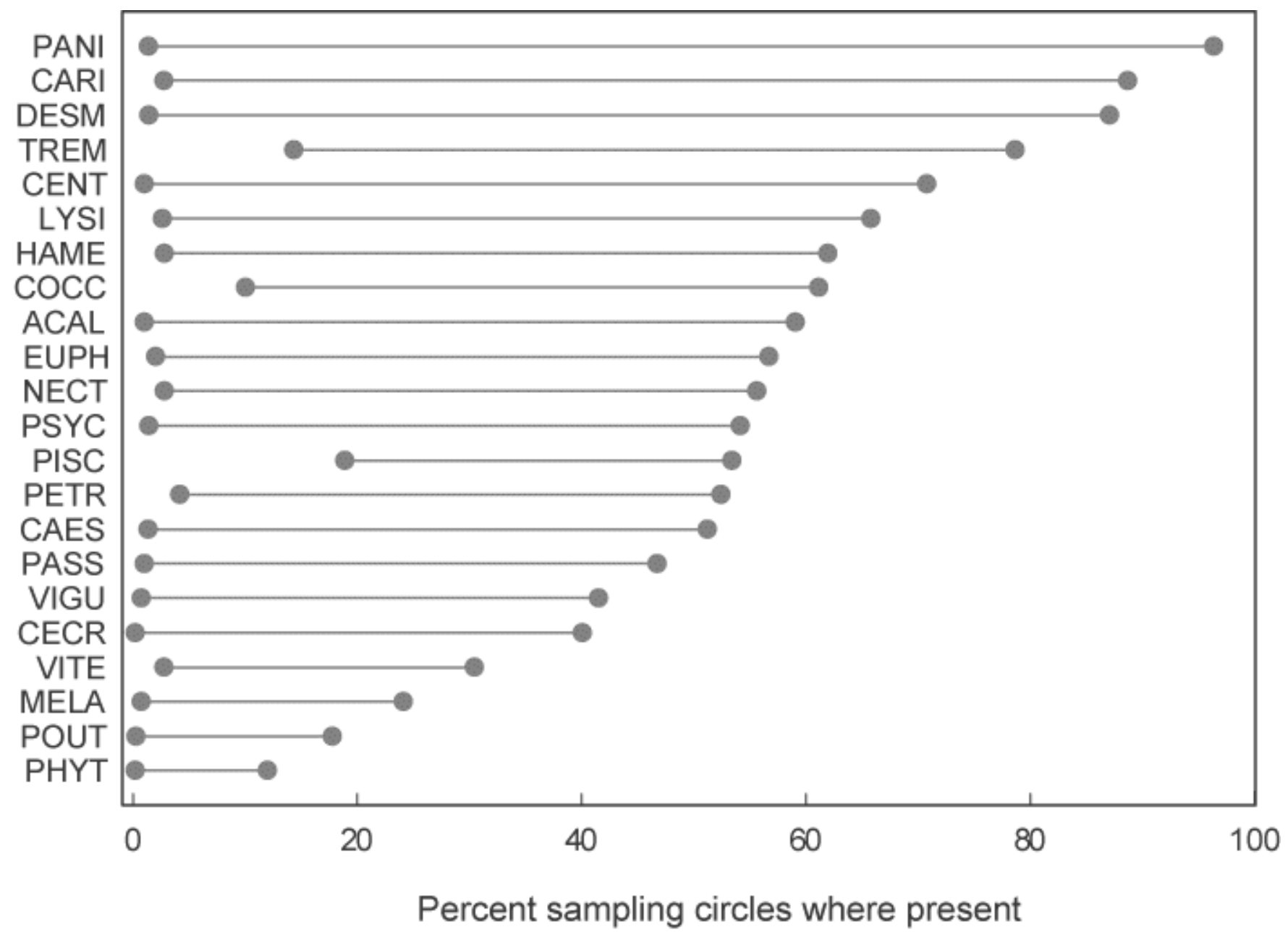

both milpas and forest patches, appears to be the most important resource affected. The availability of firewood is limited by the smaller size of spared stumps and trees in short-fallow milpas, whereas the progressive elimination of older forest patches in the areas dominated by short-fallow practices reduces the main alternative source of firewood. Although the local Maya population may adopt strategies to access more distant and firewood-rich sources or rely increasingly on an emerging firewood market, it is likely that households' capacities to respond to increased firewood scarcity in the most accessible areas will differ according to economic, labor and other factors.
The 17 forage species showed mixed responses to fallow history according to different reproductive strategies that are selected for in short vs. long fallow cycles. Forage-dependent households may be able to substitute increasingly scarce resources with those weedy species favored in the short-fallow milpas or with other species managed in home gardens or ruderal environments. However, the ecological trends apparent in the forage data, i.e., decline of pioneer trees and animal-dispersed species, accompanied by the increase in certain short-lived weedy species, indicate that the regenerative capacity of the fallows may be reduced in short-fallow milpas with implications for 
Fig. 6. Correlation biplot from the redundancy analysis (RDA) of the relative frequency of 17 forage and 5 firewood species constrained by forest type, fallow history, and rockiness. In this biplot, correlations between species and the quantitative explanatory variables fallow length, number of cycles, and rockiness are represented by the angle between their vectors, such that the smaller the angle, the stronger the association. The relationship of forest type, YK or KL, with species or with other quantitative variables can be inferred by projecting its centroid on the vector at a right angle; projections at more extreme ends of the vector indicate a stronger relationship between the variables. Finally, the length of a species' vector indicates the amount of its variation explained by the first two axes of the ordination. Species' codes as in Tables 1 and 2. The five species used for firewood are indicated by an asterisk.

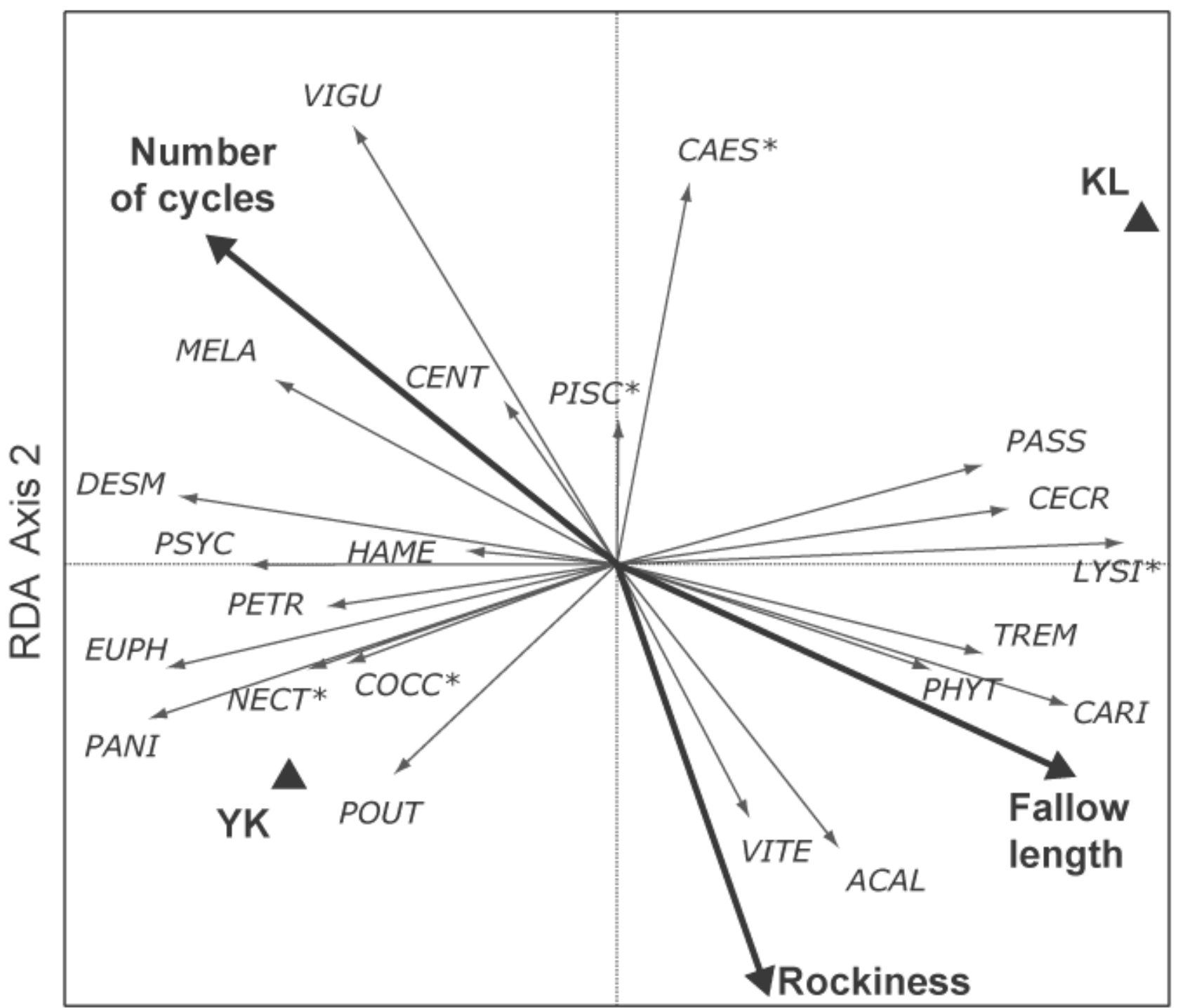

RDA Axis 1 
Table 5. Summary of species' responses to fallow history, and associated characteristics. Note that species are arranged from those most strongly associated to long fallow cycles at the top (Carica papaya) to those most strongly associated to short cycles (Viguiera dentata) at the bottom.

\begin{tabular}{|c|c|c|c|c|}
\hline Species & Life form & $\begin{array}{l}\text { Presence in mature } \\
\text { forest }^{1}\end{array}$ & $\begin{array}{c}\% \text { plots where occurred } \\
\text { as resprout }\end{array}$ & Dispersal by animals ${ }^{3}$ \\
\hline \multicolumn{5}{|l|}{ LONG FALLOW CYCLES } \\
\hline Carica papaya & Pioneer tree & - & & $*$ \\
\hline Acalypha unibracteata & Shrub & - & & \\
\hline Vitex gaumeri & Tree & + & 91.3 & $*$ \\
\hline Trema micrantha & Pioneer tree & - & 2.5 & $*$ \\
\hline Phytolacca icosandra & Forb & - & & $*$ \\
\hline Lysiloma latisiliquum & Tree & + & 10.3 & \\
\hline Cecropia peltata & Pioneer tree & - & 6.2 & $*$ \\
\hline Passiflora pedata & Vine & - & & $*$ \\
\hline \multicolumn{5}{|l|}{ NEUTRAL RESPONSE } \\
\hline Pouteria campechiana & Tree & + & 96.7 & $*$ \\
\hline Nectandra coriacea & Tree & + & 93.9 & $*$ \\
\hline Coccoloba spicata & Tree & + & 90.0 & \\
\hline Piscidia piscipula & Tree & + & 82.6 & \\
\hline \multicolumn{5}{|l|}{ SHORT FALLOW CYCLES } \\
\hline Centrosema schotti & Vine & - & & \\
\hline Petrea volubilis & Woody vine & + & & \\
\hline Panicum sp. & Grass & - & & \\
\hline Psychotria nervosa & Shrub & - & & $*$ \\
\hline Hamelia patens & Shrub & - & & $*$ \\
\hline Caesalpinia gaumeri & Tree & + & 94.1 & \\
\hline Euphorbia heterophylla & Forb & - & & \\
\hline Melanthera aspera & Shrub & - & & \\
\hline Desmodium incanum & Shrub & - & & \\
\hline Viguiera dentata & Shrub & - & & \\
\hline
\end{tabular}

${ }^{1}$ Based on a floristic inventory of different successional stages carried out in X-Maben (Correa Cano 2004) and field observations; + present, - absent in mature forest.

${ }^{2}$ For trees only; based on data from this study.

${ }^{3}$ Species for which endozoochory is reported in the literature or assumed based on fruit type (fleshy fruits). 
Fig. 7. Percentage of species variation explained by three fractions, after controlling for forest type: [a] fallow history only, [b] joint effect of fallow history and rockiness, and [c] and rockiness only. Species are arranged according to their response to the first two fractions. Negative values for the joint fallowrockiness fraction occur in some cases because this fraction is calculated by subtraction rather than directly estimated. In these cases, the species variation is better explained by rockiness and fallow history together than by the sum of their independent effects (Legendre and Legendre 1998:532-533). Species' codes as in Tables 1 and 2.

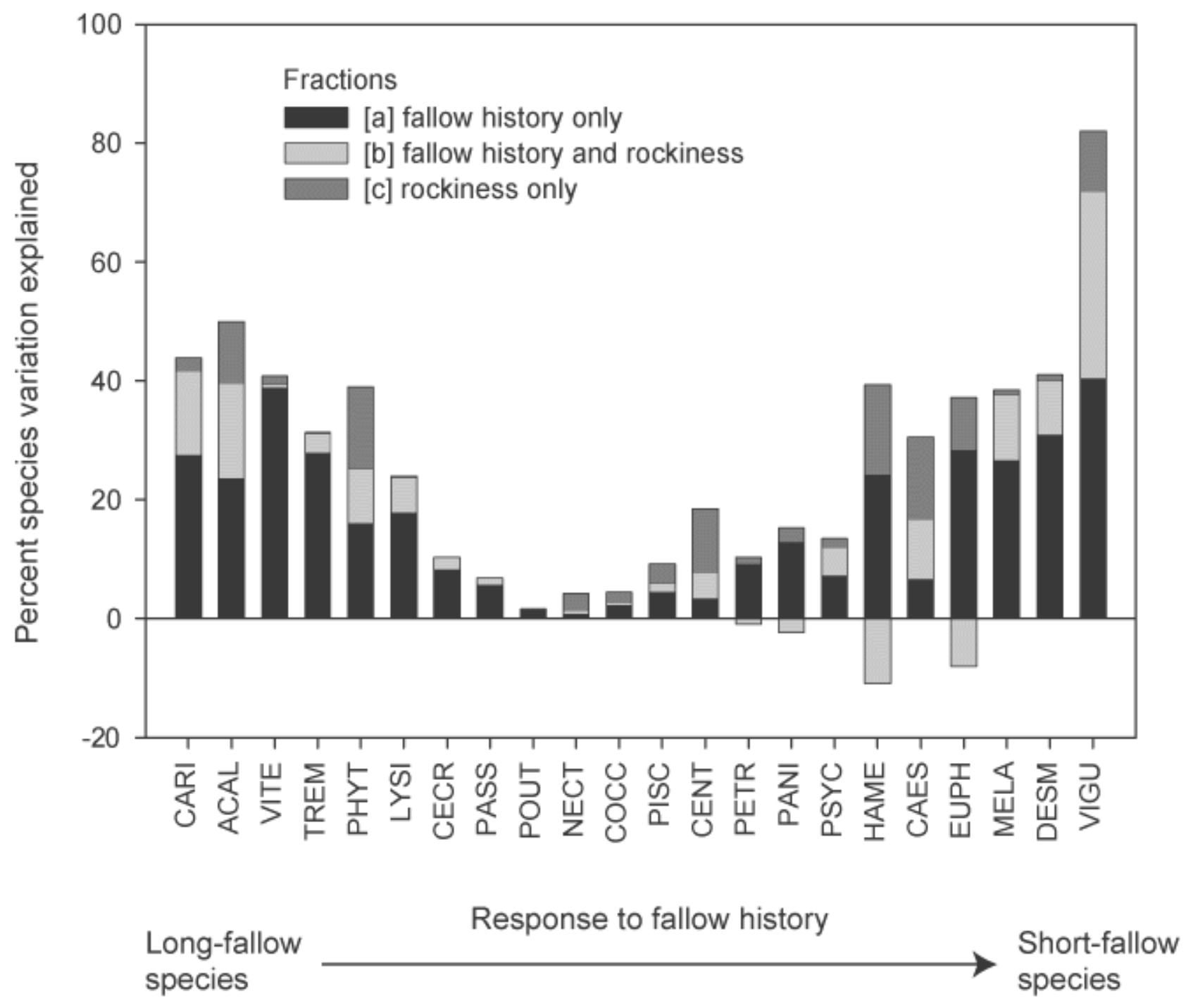


Fig. 8. Proposed relationships between changes in fallow cycles and the availability of forage and firewood (FW) resources. Solid lines indicate relationships that are demonstrated by our data, indicated by an asterisk, or supported by other studies. References are indicated by letters. Dotted arrows indicate hypothesized relationships requiring further examination. Supporting literature: (a) Saxena and Ramakrishnan 1984; (b) Young et al. 1987, Staver 1991, Rico-Gray and Garcia-Franco 1992, QuintanaAscencio et al. 1996; (c) Mertzger 2003, Lawrence 2004; (d) Saxena and Ramakrishnan 1984, Staver 1991, de Rouw 1995; (e) Suggested by Lawrence 2004; (f) Competitive exclusion by aggressive shortfallow species, suggested by Purata 1986; (g) Suggested by Lawrence 2004, Lawrence et al. 2005, although no evidence for this relationship found in the present study (see discussion).

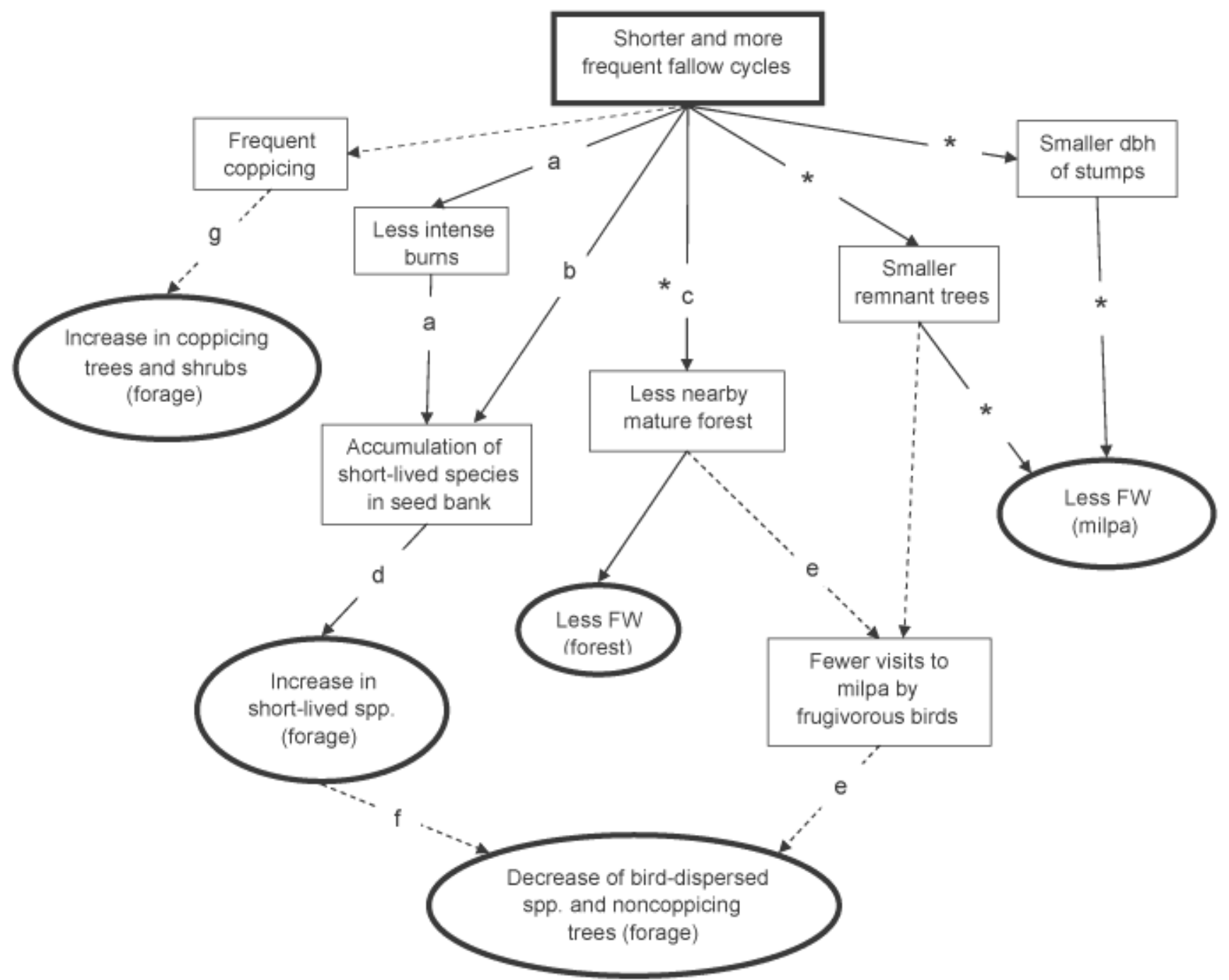


maintaining effective fallow cycles. The dynamics of noncrop plant resources and their implications for local livelihoods require further consideration in the debate over improving the productivity of shifting cultivation systems.

Responses to this article can be read online at: http://www.ecologyandsociety.org/voll1/iss2/art2/responses/

\section{Acknowledgments:}

We would like to extend special thanks to the people of Ejido X-Maben for their friendship and support during the study, and especially to the Poot Pat and Cituk Chi families for their hospitality. We are indebted to Wenceslao Pat Canche, Brigido Cituk Peña, and Luis Cauich for their dedicated collaboration throughout the project and for sharing their vast ecological knowledge with us. Brigido's keen observations and guidance in the field drew SPD's attention to the importance of fallow history for understanding current vegetation patterns. Institutional support during fieldwork was provided by Dr. Javier Caballero at the Universidad Nacional Autónoma de México. Discussions with Dr. Caballero and other colleagues at UNAM, as well as with Cati Illsley of GEA, contributed significantly to the conceptual development of this project. Maria Eugenia Correa Cano and the staff at MEXU provided invaluable assistance in identifying voucher specimens. Helpful comments from two anonymous reviewers and from T. Johns and T. Ticktin are also acknowledged. Fieldwork was funded by an IDRC Doctoral Research Award from the International Development Research Centre (Ottawa). SPD also acknowledges support from the Fonds Québecois de Recherches sur la Nature et les Technologies, the Natural Science and Engineering Research Council of Canada, the Celanese Canada Internationalist program and the Secretaría de Relaciones Exteriores (Mexico).

\section{LITERATURE CITED}

Acosta Bustillos, L. E., J. S. Flores Guido, and A. Gómez Pompa. 1998. Uso y manejo de plantas forrajeras para cria de animales dentro del solar en una comunidad Maya en Yucatán. Etnoflora Yucatanense Number 14. Universidad Autónoma de Yucatán, Merida, Yucatán, México.

Alcorn, J. B. 1981. Huastec noncrop resource management: implications for prehistoric rain forest management. Human Ecology 9(4):395-417.

Alvarez-Buylla, E. R., and M. Martinez-Ramos. 1990. Seed bank versus seed rain in the regeneration of a tropical pioneer tree. Oecologia 84(3):314-325.

Barrera-Bassols, N., and V. M. Toledo. 2005. Ethnoecology of the Yucatec Maya: symbolism, knowledge and management of natural resources. Journal of Latin American Geography 4(1):9-41.

Brookfield, H. 2001. Exploring agrodiversity. Columbia University Press, New York, New York, USA.

Brouwer, I. D., J. C. Hoorweg, and M. J. Vanliere. 1997. When households run out of fuel: responses of rural households to decreasing fuelwood availability, Ntcheu District, Malawi. World Development 25(2):255-266.

Bye, R. A. 1981. Quelites: ethnoecology of edible greens-past, present and future. Journal of Ethnobiology 1(1):109-123.

Caballero, J. 1994. Use and management of Sabal palms among the Maya of Yucatán. Dissertation. Department of Anthropology, University of California at Berkeley, Berkeley, California, USA.

Carriere, S. M., P. Letourmy, and D. B. McKey. 2002a. Effects of remnant trees in fallows on diversity and structure of forest regrowth in a slashand-burn agricultural system in southern Cameroon. Journal of Tropical Ecology 18(3):375-396.

Carriere, S. M., M. Andre, P. Letourmy, I. Olivier, and D. B. McKey. 2002b. Seed rain beneath remnant trees in a slash-and-burn agricultural system in southern Cameroon. Journal of Tropical Ecology 18(3):353-374.

Colfer, C. J. P., N. Peluso, and C. S. Chung. 1997. Beyond slash and burn: building on indigenous management of Borneo's tropical rain forests. New York Botanical Garden, Bronx, New York, USA.

Correo Cano, M. E. 2004. Los recursos vegetales en el paisaje fragmentado generado por la agricultura itinerante: un estudio de caso en el area 
Maya Yucateca de Mexico. Tesis de Licenciatura, Facultad de Ciencias, Universidad Nacional Autonoma de Mexico, México, D.F., México.

Dalle, S. P. 2006. Landscape dynamics and management of wild plant resources in shifting cultivation systems: a case study from a forest ejido in the Maya Zone of Quintana Roo, Mexico. Dissertation. Department of Plant Science, McGill University, Montréal, Québec, Canada.

Dalle, S. P., S. de Blois, J. Caballero, and T. Johns. 2006. Integrating analyses of local land-use regulations, cultural perceptions and land-use/land cover data for assessing the success of communitybased conservation. Forest Ecology and Management 222(1-3):370-383.

Dalling, J. W., M. D. Swaine, and N. C. Garwood. 1998. Dispersal patterns and seed bank dynamics of pioneer trees in moist tropical forest. Ecology 79 (2):564-578.

de Rouw, A. 1995. The fallow period as a weedbreak in shifting cultivation (tropical wet forests). Agriculture, Ecosystems and Environment 54:31-43.

Esteva, G., and C. Marielle. 2003. Sin maíz no hay país. CONACULTA, México, D.F., México.

Finegan, B., and R. Nasi. 2004. The biodiversity and conservation potential of shifting cultivation landscapes. Pages 153-197 in G. Schroth, G. A. B. da Fonseca, C. A. Harvey, C. Gascon, H. L. Vasconcelos, and A.-M. N. Izac, editors. Agroforestry and biodiversity conservation in tropical landscapes. Island Press, Washington, D. C., USA.

Flores, J. S., and I. Espejel Carvajal. 1994. Tipos de Vegetación de la Peninsula de Yucatán. Etnoflora Yucatense Number 3. Universidad Autonoma de Yucatan, Merida, México.

Frei, B., O. Sticher, M. Heinrich. 2000. Zapotec and Mixe use of tropical habitats for securing medicinal plants in Mexico. Economic Botany 54 (1):73-81.

Fujisaka, S., G. Escobar, and E. J. Veneklaas. 2000. Weedy fields and forests: interactions between land use and the composition of plant communities in the Peruvian Amazon. Agriculture, Ecosystems and Environment 78:175-186.
Gomez-Pompa, A., and C. Vazquez-Yanes. 1981. Successional studies of a rain forest in Mexico. Pages 246-266 in D. C. West, H. H. Shugart, and D. B. Botkin, editors. Forest succession: concepts and applications. Springer-Verlag, New York, New York, USA.

Guevara, S., S. E. Purata, and E. Van der Maarel. 1986. The role of remnant forest trees in tropical secondary succession. Vegetatio 66:77-84.

Hostettler, U. 1996. Milpa agriculture and economic diversification: socioeconomic change in a Maya peasant society of Central Quintana Roo, 1900-1990s. Dissertation. Institut für Ethnologie, University of Berne, Berne, Switzerland.

Illsley Granich, C. 1984. Vegetación y producción de la milpa bajo roza-tumba-quema en el ejido de Yaxcaba, Yucatán, México. Tésis de Licenciatura, Escuela de Biología, Universidad Michoacana de San Nicolas de Hidalgo, Morelia, México.

Illsley Granich, C., E. Hernández Xolocotzi. 1980. La vegetación en relación a la producción agrícola en el ejido de Yaxcaba, Yucatán. Pages 343-372 in E. Hernández Xolocotzi, editor. Seminario sobre producción agrícola en Yucatán. Gobierno del Estado de Yucatán, Merida, México.

INEGI. 2000. XII Censo general de población y vivienda. 2000. Quintana Roo. Resultados difinitivos. Instituto Nacional de Estadística Geografía e Informática, Aguascalientes, México.

Instituto de Geografía. 1990. Atlas nacional de México . Universidad Nacional Autónoma de México, México, D.F., México.

Johns, T. 1994. Ambivalence to the palatability factors in wild food plants. Pages in N. Etkin, editor. Eating on the wild side: the pharmacologic, ecologic and social implications of using noncultigens. University of Arizona Press, Tucson, Arizona, USA.

Kellman, M., and R. Tackaberry. 1997. Tropical environments: the functioning and management of tropical ecosystems. Routledge, London, UK.

Lawrence, D. 2004. Erosion of tree diversity during 200 years of shifting cultivation in Bornean rain forest. Ecological Applications 14(6):1855-1869. 
Lawrence, D., V. Suma, and J. P. Mogea. 2005. Change in species composition with repeated shifting cultivation: limited role of soil nutrients. Ecological Applications 15(6):1952-1967.

Lawrence, D., H. F. M. Vester, D. Pérez-Salicrup, J. R. Eastman, B. L. Turner II, and J. Geoghegan. 2004. Integrated analysis of ecosystem interactions with land-use change: the southern Yucatán peninsular region. Pages 277-292 in R. S. DeFries, G. P. Asner, and R. A. Houghton, editors. Ecosystems and land use change. American Geophysical Union, Washington, D.C., USA.

Legendre, P., and L. Legendre. 1998. Numerical ecology. Second edition. Elsevier, Amsterdam, The Netherlands.

Legendre, P., and E. D. Gallagher. 2001. Ecologically meaningful transformations for ordination of species data. Oecologia 129:271-280.

Levy Thatcher, S., and E. Hernández Xolocotzi. 1992. La sucesión secundaria en Yucatán y su manejo. Pages 203-214 in D. Zizumbo Villarreal, C. H. Rasmussen, L. M. Arias Reyes, and S. Teran Contreras, editors. La modernización de la milpa en Yucatán: utopia o realidad. Centro de Investigación Científica de Yucatán, Merida, México.

Mahiri, I. O. 2003. Rural household responses to fuelwood scarcity in Nyando District, Kenya. Land Degradation and Development 14(1):163-171.

Martinez-Garza, C., and R. Gonzalez-Montagut. 1999. Seed rain from forest fragments into tropical pastures in Los Tuxtlas, Mexico. Plant Ecology 145:255-265.

Mazhar, F., and D. Buckles. 2000. Cultivating the landscape: enhancing the context for plant improvement. IDRC, Ottawa, Ontario, Canada.

Mertz, O. 2002. The relationship between length of fallow and crop yields in shifting cultivation: a rethinking. Agroforestry Systems 55:149-159.

Metzger, J. P. 2003. Effects of slash-and-burn fallow periods on landscape structure. Environmental Conservation 30(4):325-333.

Murphy, J. 1990. Indigenous forest use and development in the Maya zone of Quintana Roo, Mexico. Major Paper, Environmental Studies, York
University, Toronto, Ontario, Canada.

Nyerges, A. E. 1989. Coppice swidden fallows in tropical deciduous forest: biological, technological and sociocultural determinants of secondary forest successions. Human Ecology 17(4):379-400.

Pennington, T. D., and J.Sarukhán. 1998. Árboles tropicales de México. Universidad Nacional Autónoma de México, México, D.F., México.

Pohl, M., and L. H. Feldman. 1982. The traditional role of women and animals in lowland Maya economy. Pages 295-312 in K. V. Flannery, editor. Maya subsistence. Academic Press, New York, New York, USA.

Pulido, M. T., and J. Caballero. 2006. The impact of shifting agriculture on the availability of nontimber forest products: the example of Sabal yapa in the Maya lowlands of Mexico. Forest Ecology and Management 222(1-3):399-409.

Purata, S. E. 1986. Floristic and structural changes during old-field succession in the Mexican tropics in relation to site history and species availability. Journal of Tropical Ecology 2:257-276.

Quintana-Ascencio,P.F., M. Gonzalez-Espinosa, N. Ramirez-Marcial, G. Dominguez-Vazquez, and M. Martinez-Ico. 1996. Soil seed banks and regeneration of tropical rain forest from milpa fields at the Selva Lacandona, Chipas, Mexico. Biotropica 28(2):192-209.

Ramakrishnan, P. S. 1992. Shifting agriculture and sustainable development: an interdisciplinary study from North-Eastern India. UNESCO, Paris, France.

Read, L., and D. Lawrence. 2003. Recovery of biomass following shifting cultivation in dry tropical forests of the Yucatan. Ecological Applications 13(1):85-97.

Rico-Gray, V., and J. G. Garcia-Franco. 1992. Vegetation and soil seed bank of successional stages in tropical lowland deciduous forest. Journal of Vegetation Science 3:617-624.

Sanchez Sanchez, O., G. A. Islebe. 2002. Tropical forest communities in southeastern Mexico. Plant Ecology 158(2):183-200. 
Saxena, K. G., and P. S. Ramakrishnan. 1984. Herbaceous vegetation development and weed potential in slash and burn agriculture (jhum) in $\mathrm{N}$. E. India. Weed Research 24:135-142.

Schmidt-Vogt, D. 1997. Forests and trees in the cultural landscape of Lawa swidden farmers in northern Thailand. Pages 44-50 in K. Seeland, editor. Nature is culture: indigenous knowledge and socio-cultural aspects of trees and forests in nonEuropean cultures. Intermediate Technology, London, UK.

Staver, C. 1991. The role of weeds in the productivity of Amazonian bush fallow agriculture. Experimental Agriculture 27:287-304.

Sunderlin, W. D. 1997. Shifting cultivation and deforestation in Indonesia: steps toward overcoming confusion in the debate. Rural Development Forestry Network. Overseas Development Institute, London, UK.

Toledo, V. M., B. Ortiz-Espejel, L. Cortes, P. Moguel, and M. D. J. Ordonez. 2003. The multiple use of tropical forests by indigenous peoples in Mexico: a case of adaptive management. Conservation Ecology 7(3):9. [online] URL: http:// www.consecol.org/vol7/iss3/art9/.

Uhl, C., H. Clark, and K. Clark. 1982. Successional patterns associated with slash-andburn agriculture in the Upper Rio Negro region of the Amazon basin. Biotropica 14(4):249-254.

Vázquez-Yanes, C. 1998. Trema micrantha (L.) Blume (Ulmaceae): A promising neotropical tree for site amelioration of deforested land. Agroforestry Systems 40(1):97-104.

Vieyra-Odilon, L., and H. Vibrans. 2001. Weeds as crops: the value of maize field weeds in the valley of Toluca, Mexico. Economic Botany $\mathbf{5 5}$ (3):426-443.

Weisbach, C., H. Tiessen, and J. J. JimenezOsornio. 2002. Soil fertility during shifting cultivation in the tropical karst soils of Yucatan. Agronomie 22(3):253-263.

White, D. A., and C. S. Hood. 2004. Vegetation patterns and environmental gradients in tropical dry forests of the northern Yucatan Peninsula. Journal of Vegetation Science 15(2):151-160.
Young, K. R., J. J . Ewel, and B. J. Brown. 1987. Seed dynamics during forest succession in Costa Rica. Vegetatio 71:157-173. 